\title{
45. ORIGIN OF CLASTS AND MATRIX WITHIN THE MILANO AND NAPOLI MUD VOLCANOES, MEDITERRANEAN RIDGE ACCRETIONARY COMPLEX ${ }^{1}$
}

\author{
Alastair H.F. Robertson ${ }^{2}$ and Achim Kopf ${ }^{3}$
}

\begin{abstract}
Petrographic and mineralogical studies of clasts and matrix in the Milano and Napoli mud volcanoes drilled during Ocean Drilling Program Leg 160 provide important clues about depositional processes, provenance, and the tectonic setting of deepsea sediments that accumulated before genesis of the Mediterranean Ridge mud volcanoes.

The clasts recovered from both mud volcanoes are mainly mudstone and claystone, calcareous siltstone, quartzose sandstone and siltstone, shallow-water-derived limestone, and pelagic carbonate. Biostratigraphic evidence indicates mainly early and middle Miocene ages for fossiliferous clasts, with the older microfossils being reworked. Textural evidence (grading) suggests that the clastic lithologies are turbidites. Sources of the sandstones were mainly plutonic igneous and subordinate metamorphic rocks. Sporadic, exceptionally well-rounded, quartz grains may be of eolian origin and were probably derived from the Precambrian basement of North Africa. Shallow-water-derived carbonates were also redeposited as calciturbidites, with variable admixing with siliciclastic and pelagic carbonate, which indicates shared depositional pathways. Pelagic carbonates (packstones) were redeposited basinward as calciturbidites from a deep-sea carbonate slope that formed part of the North African continental margin. During the middle Miocene, the background sedimentation was in situ pelagic carbonate. In addition, relatively rare, texturally immature, lithic sandstones include serpentinite, basalt, and radiolarian chert, of ophiolite-related origin. This material was derived from the orogenic areas to the north, possibly originally from the higher thrust sheets of Crete, before late Miocene and subsequent erosion and extensional downfaulting.

The texture and composition of the mud and clay matrix provide clues about the mode of the mud volcanism. The matrix of the mud debris flows includes numerous, small, angular clasts of unfossiliferous claystone and shardlike fragments, which show pseudolamination, microshearing, and crosscutting veinlets, features that are taken as evidence for the involvement of high fluid pressure in clast and matrix formation (hyrofracturing).
\end{abstract}

\section{INTRODUCTION}

The Mediterranean Ridge mud volcanoes are of particular interest in view of their relation to processes of subduction/accretion and initial collision of the African and Eurasian plates (Cita and Camerlenghi, 1990; Cita et al., 1996a, 1996b; see Figs. 1, 2). Mud volcanoes south of Crete were initially not distinguished from a more widespread, seismically diffracting "cobblestone topography" (Kastens, 1981). More recently, however, the mud volcanoes were identified as "mud diapirs" on the basis of seismic reflection and piston coring studies (Cita et al., 1981, 1989, 1995, 1996a, 1996b; Camerlenghi et al., 1992, 1995). Superficial features were revealed in 1993 by sidescan sonar studies, combined with additional coring, and the Napoli mud volcano was shown to be actively venting (Limonov et al., 1994). Two of the mud structures, the Milano and Napoli mud volcanoes, were drilled during April 1995 as part of Ocean Drilling Program Leg 160 (Emeis, Robertson, Richter, et al., 1996; Robertson et al., 1996; Fig. 1). Additional dredging, sidescan sonar imaging, and coring were conducted on these and adjacent mud volcanoes later that year (Limonov et al., 1995).

Piston coring during several cruises demonstrated the presence of distinctive "mud breccias" composed of various clasts in a mud-rich matrix. Initial petrographic studies of the clasts revealed a range of lithologies, including quartzose sandstones and limestones. The presence of planktonic foraminifers and calcareous nannofossils indicated mainly Tertiary, and rarely Cretaceous, ages for the clasts and ma-

${ }^{1}$ Robertson, A.H.F., Emeis, K.-C., Richter, C., and Camerlenghi, A. (Eds.), 1998. Proc. ODP, Sci. Results, 160: College Station, TX (Ocean Drilling Program).

${ }^{2}$ University of Edinburgh, Department of Geology and Geophysics, West Mains Road, Edinburgh, EH9 3JW, United Kingdom. Alastair.Robertson@glg.ed.ac.uk

${ }^{3}$ Geologisches Institut, Albert-Ludwigs-Universität Freiburg, Albertstrasse 23B 79104 Freiburg, Federal Republic of Germany. trix (Staffini et al., 1993; Premoli-Silva et al., 1996). Two views of the origin of the mud breccias were previously considered: that they represented a combination of both intrusive and extrusive processes (Camerlenghi et al., 1992; Staffini et al., 1993; Cita et al., 1996a), or that they were composed entirely of sedimentary debris flows extruded from individual mud volcanoes (Limonov et al., 1994). Debris flow deposits are defined as sediments composed of clasts in a muddy matrix where the texture is mud supported (see Emeis, Robertson, Richter, et al., 1996, for a discussion of terminology).

The two alternate hypotheses were tested by drilling a transect of shallow holes, up to $200 \mathrm{~m}$ below seafloor (mbsf) across the flanks of the Milano and Napoli mud structures (Fig. 3; Emeis, Robertson, Richter, et al., 1996; Robertson and Leg 160 Scientific Party, 1996). The main results were, first, that both are true mud volcanoes, dominated by stratified mud- and clast-rich sediments, interpreted as multiple debris flows (down to $200 \mathrm{mbsf}$ ), and second, that the stratified mud-rich sediments are interlayered with deep-water hemipelagic sediments. Biostratigraphic dating shows that the Napoli mud volcano began activity more than $1 \mathrm{Ma}$, whereas Milano became active about 1.5 Ma.

During Leg 160, shipboard analysis showed that the clasts in the mud volcano that could be dated biostratigraphically yielded earlymiddle Miocene ages, on the basis of planktonic foraminifers and calcareous nannofossils (Emeis, Robertson, Richter, et al., 1996). These clasts commonly also contain reworked microfossils of Oligocene, Miocene, and Cretaceous age. Eocene, Oligocene, and middle Miocene nannofossils are also dispersed through the matrix, which may, however, be partly of Messinian age, as discussed below.

Samples of mud volcano sediment were previously cored by the Bannock in 1988 and 1989 from three areas, including Olimpi (Camerlenghi et al., 1992; Fig. 2). Petrographic results were reported from a small number of samples (Staffini et al., 1993). Much additional petrographic information from gravity coring of eight mud volcanoes (not including Milano or Napoli) by the Gelendzhik indicated that the 
compositions of the clasts and matrix of individual mud volcanoes are broadly similar, although some local differences remain poorly understood (Akhmanov, 1996). X-ray diffraction (XRD) results conducted previously indicate a predominance of smectite, mixed-layer clays, and kaolinite, with minor illite and chlorite (Staffini et al., 1993; Akhmanov, 1996). The previous XRD analysis includes seven samples from Napoli and one from Milano (Staffini et al., 1993).

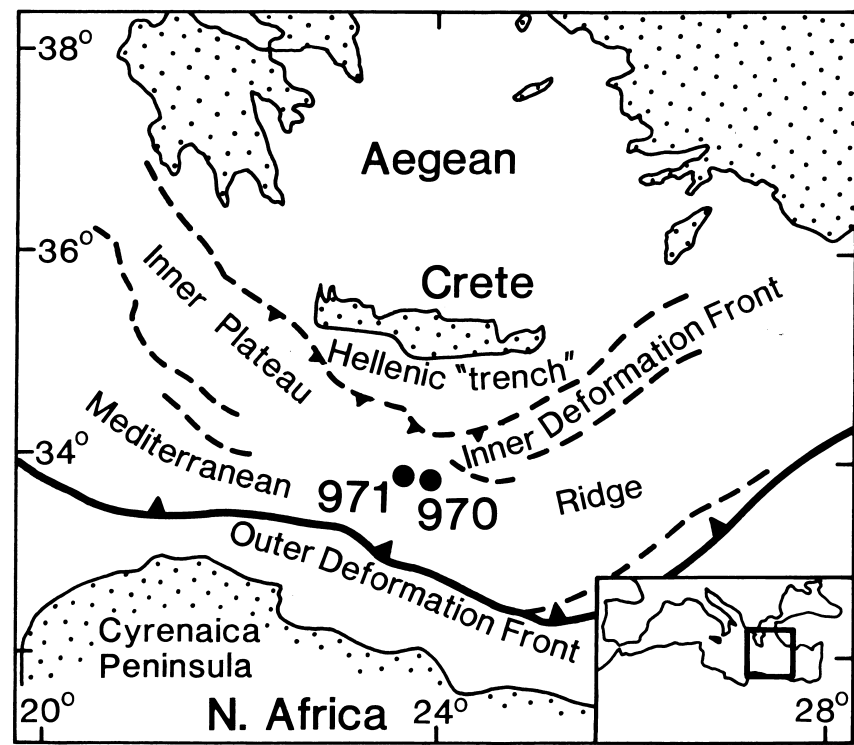

Figure 1. Tectonic setting of the Milano (Site 970) and Napoli (Site 971) mud volcanoes on the Mediterranean Ridge south of Crete. These volcanoes are located on the northern part of the Inner Plateau area, adjacent to the Hellenic Trench to the north. Note the location of the Cyrenaica Peninsula of the North African continental margin to the south (upper right). The mud volcanoes are located in an area where the Mediterranean Ridge is backthrust northward toward Crete, forming the Inner Deformation Front.
Nevertheless, drilling during Leg 160 provided the first opportunity to recover mud volcano sediments from up to $200 \mathrm{mbsf}$.

The main aim of this paper is to report evidence from optical petrography, XRD, and scanning electron microscopy (SEM) for the composition of the clasts and matrix of both the mud volcanoes, and to use this information to interpret, as far as possible, the depositional and tectonic setting of the region before mud volcanism. Some features of the clasts and matrix also shed light on the processes of mud volcanism.

\section{METHODS \\ Petrographic Studies}

As a result of a gradational change from clayey matrix to particles of submillimeter to centimeter range, the meaning of "clasts" vs. "matrix" must be defined. In general, most particles that could be identified using the unaided eye, such as lithology or shape, were mudclasts and mudstone clasts. Clasts $>1 \mathrm{~cm}$ across were typically mudstone clasts or well-lithified sandstone and limestone. The clast size is directly related to the degree of lithification (the largest samples studied in thin section were siliceous litharenites; see also Flecker and Kopf, 1996). We define clasts arbitrarily as small particles that are readily observable by visual inspection (i.e., $>5 \mathrm{~mm}$ ). The matrix is finer grained, but commonly includes individual larger grains (1$5 \mathrm{~mm}$ in diameter) that were largely mudstones. We concentrate on the larger clasts $(>1 \mathrm{~cm})$ because they yield useful petrographic and biostratigraphic data.

Clasts were studied using optical petrography (79 samples), and an additional five samples of the matrix were examined using impregnated thin sections. Studies of clasts provide insights into deposition in the Mediterranean Ridge area before the onset of mud volcanism. The nature of the matrix also provides clues concerning the processes of mud volcanism. Furthermore, 149 samples of the finegrained matrix of the Napoli mud volcano (Site 971) and 35 samples from the Milano mud volcano (Site 970) were subjected to bulk XRD analysis to elucidate provenance and diagenesis. Also, a small number of these samples underwent glycolation and differential thermal analysis to confirm identification of clay minerals. Finally, several samples were studied using SEM to identify surface textures.
Figure 2. Location of the Napoli and Milano mud volcanoes within the Olimpi field of mud volcanoes (inset), located to the south of the Inner Deformation Front of the Mediterranean Ridge accretionary complex.

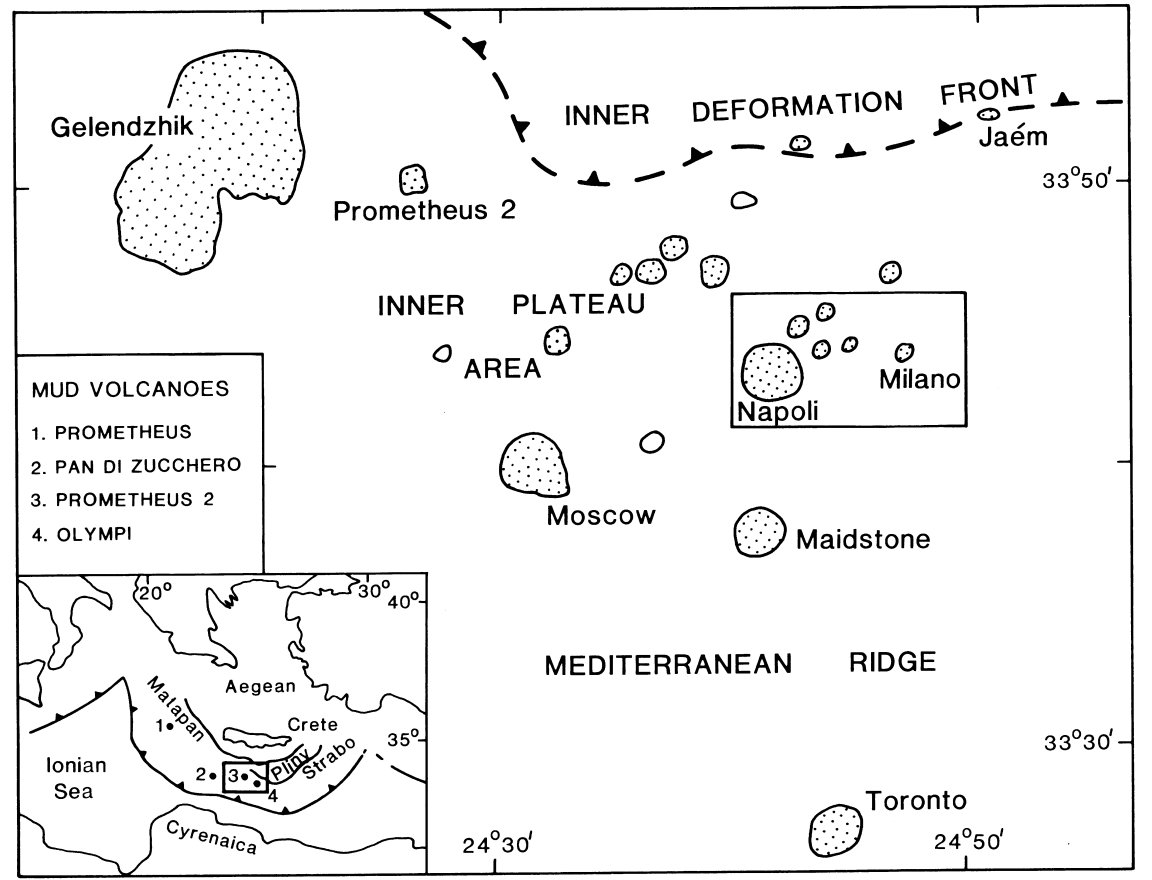



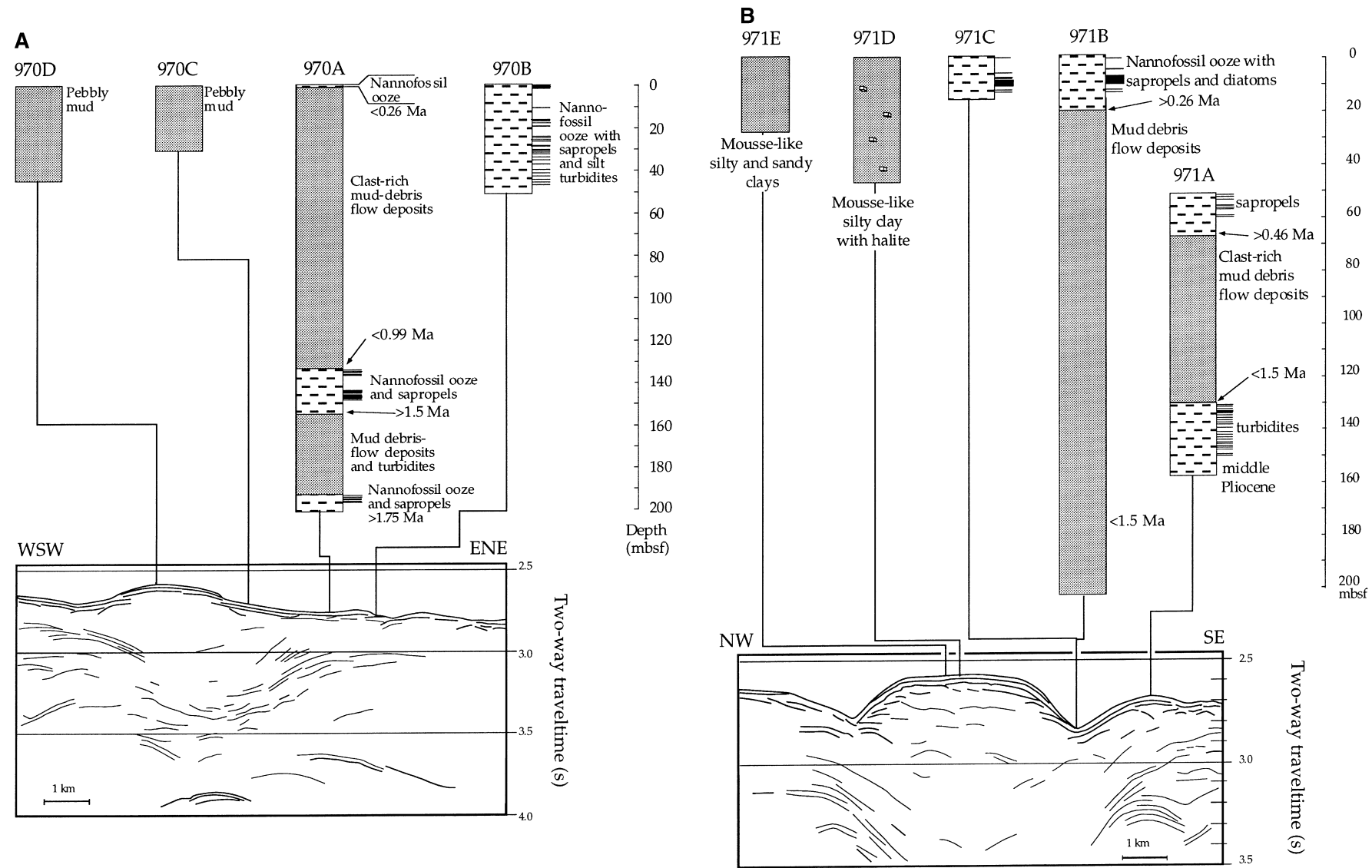

Figure 3. Summary of the sedimentary successions of the (A) Milano (Site 970) and (B) Napoli (Site 971) mud volcanoes drilled during Leg 160. The inferred age ranges of associated in situ deep-water hemipelagic sediments are also shown. The lower part of the cored intervals in the deep holes (200 mbsf) and in the flanks of both mud volcanoes comprises well-layered mud-rich debris flows and graded terrigenous silts. These units are overlain by clast-bearing mud-rich sediments, interpreted as multiple debris flows (redrawn from Emeis, Robertson, Richter, et al., 1996).

\section{PETROGRAPHIC ANALYSIS Clasts}

\section{Claystones and Mudstones}

Most claystone and mudstones clasts are $<1 \mathrm{~cm}$ in size and cannot easily be distinguished from the matrix. The clasts were rarely sufficiently well consolidated to cut thin sections without impregnation. Consequently, we have studied them in less detail than the more lithified clasts, described below. The mudstone clasts are typically silty, and are massive or weakly laminated. In several cases (Samples 160970D-3H-CC, 17-20 cm, 971A-6X-CC, 3-6 cm, 971B-17X-2, 20$22 \mathrm{~cm}$ ), the clay is either homogeneous or contains scattered small angular quartz grains. Planktonic foraminifers and other bioclasts were not observed. The lamination of the mudstones can be explained by the alignment of muscovite (Sample 160-971B-17X-2, 20-22 $\mathrm{cm})$. Much of the clay has a finely parallel laminated appearance, which may not be entirely of primary origin, as discussed below. Rare phosphatic grains and common disseminated pyrite are also present. Rare claystone clasts (Sample 160-970D-3H-CC, 17-20 cm) contain abundant framboidal pyrite. Elongate granular pyrite is present, possibly as a burrow fill.

\section{Quartzose Sandstones}

Clasts studied from both the Napoli and Milano mud volcanoes were predominantly litharenites. Contrasting lithic sandstones were identified with markedly differing compositions.
Individual sandstones (Samples 160-970D-5H-2, 61-64 cm, 970C-1H-3, 55-59 cm, and 970C-3H-5, 73-75 cm) are mainly fine to medium grained, well sorted, and well indurated (Pl. 1). Quartz grains are mainly angular to subangular to subrounded. Individual grains are typically intact and clear and are thus interpreted as mainly unstrained. One of the sandstone clasts, however, is broken and exhibits minute slickensides on a planar faulted surface (Sample 160971A-7X-01, 44-48 cm). Because this brittle deformation does not affect the adjacent grains, we assume that deformation occurred within the source area and was not related to mud volcanism. Vacuoles and rutile inclusions are visible locally. Some irregular, unstrained quartz grains exhibit embayed margins, which are filled with clay (Samples 160-970C-4X-1, 9-12 cm, and 970A-1H-2, 127-130 cm). These embayments probably resulted from grain alteration, either in the source area or during diagenesis.

Additional subordinate minerals and lithoclasts within the litharenites are polycrystalline quartz, schist, plagioclase (both fresh and altered grains), orthoclase, perthite, microcline, augite, hornblende, epidote, muscovite, biotite, and chloritized ferromagnesian grains (Pl. 1). Other heavy minerals include zircon, tourmaline, rutile, apatite, and very rare spinel. Scattered echinoderm plates, shell fragments, and planktonic foraminifers are locally present. Chloritized ferromagnesian grains and glauconite pellets are rare. Sample 160970A-9X-1, 63-65 cm, contains numerous millimeter-sized clay intraclasts (pellets). A volumetrically minor matrix of mud-rich micrite is present locally (Sample 160-970A-1H-5, 83-85 cm).

Sporadic, compositionally contrasting, lithoclastic sandstones, siltstones, and mixed siliciclastic-carbonate sediments were observed 
in clasts both from the Napoli (Samples 160-971A-5X-CC, 29-35 $\mathrm{cm}$, and 971B-20X-3, 9-10 cm) and Milano (Sample 160-970C-1H$2,1-3 \mathrm{~cm}$ ) mud volcanoes (Pl. 2). Small fragments and individual grains of similar composition material were also noted in the matrix of the Milano mud volcano sediments.

Two such clasts from the Napoli mud volcano were studied in detail (Samples 160-971A-5X-CC, 25-35 cm, and 971B-20X-3, 9-10 $\mathrm{cm})$. Both are moderately well sorted, texturally immature, lithoclastic sandstones. The following components are present in decreasing order of abundance: quartz, polycrystalline quartz (Pl. 2), quartzose schist (psammite), schist with metamorphic plagioclase (albite), muscovite, biotite, and partly recrystallized quartzose silt. Quartz grains are angular and highly strained. Locally abundant, angular to subrounded lithoclasts of chert are also present. Clasts of radiolarianbearing chert (with clearly identifiable radiolarians) are set in a matrix of red (ferruginous) microcrystalline quartz (Pl. 2). Individual radiolarians are filled with chalcedonic and drusy quartz. Other chert clasts range from recrystallized radiolarian chert, in which radiolarians remain visible as "ghosts," to totally recrystallized quartzose chert. In addition, numerous, mainly subangular, lithoclasts of altered basic extrusives contain feldspar microphenocrysts in a finely crystalline matrix (Pl. 2). A volumetrically minor micritic matrix (up to $15 \%$ ) is partly recrystallized to sparry calcite. Planktonic foraminifers and other bioclasts were not observed in this sample.

The composition of an area and its plate tectonic setting both strongly influence sand and sandstone compositions (Dickinson and Suzcek, 1979). Thus, framework modal compositions were counted for representative sandstone clasts from both the Milano and Napoli mud volcanoes. Point counting was restricted to quartz (Q), feldspar (F), and lithics (L) (Fig. 4A). A slightly varied ternary system (Fig. 4B) distinguishes between monocrystalline quartz (Qm) and polycrystalline quartz, which is added to the lithics (Lt, for total lithics, including the metamorphic, polycrystalline quartz component). Depending on the mean grain size and the size of the thin section, between 114 and 652 grains per sample were counted. The QFL plot shows that the sediment is dominated by quartz, plots predominantly in the "recycled orogenic" field, and sporadically in the "transitional continental" field (Fig. 4A). If the polycrystalline quartz is added to the lithics (Fig. 4B), two distinct groups can be identified. The texturally mature sandstones still lie within the transitional field, whereas the immature sandstones with strained, broken quartz are separated toward the lithic field. This reflects an abundance of lithologically different grains (serpentinite, basalt, radiolarian chert, and metamorphics), which suggests a contrasting source area.

\section{Siltstones}

Sporadic clasts are composed almost entirely of well-sorted quartzose siltstone with minimal matrix (Sample 160-970C-3H-2, 58-62 $\mathrm{cm})$. However, several clasts of calcareous siltstone were recovered (Samples 160-971A-2H-5, 106-108 cm, and 970D-2H-5, 119-120 $\mathrm{cm})$. Quartz grains are mainly angular to subrounded, or rarely rounded. Most of the quartz is clear and unstrained (with some vacuoles); however, some polycrystalline grains and muscovite schist are also present. Rare grains of muscovite, biotite (foliated), plagioclase, orthoclase, perthite, and microcline were also noted. Numerous tiny lithoclasts are composed mainly of clay; these are typically rounded to subrounded and occur together with rare, small, angular clasts of crystalline limestone. The clay lithoclasts commonly contain small elongate voids. The possible origins of these voids are discussed below. Scattered shell fragments are also present, some with sparry calcite cement attached. Sporadic planktonic foraminifers are also
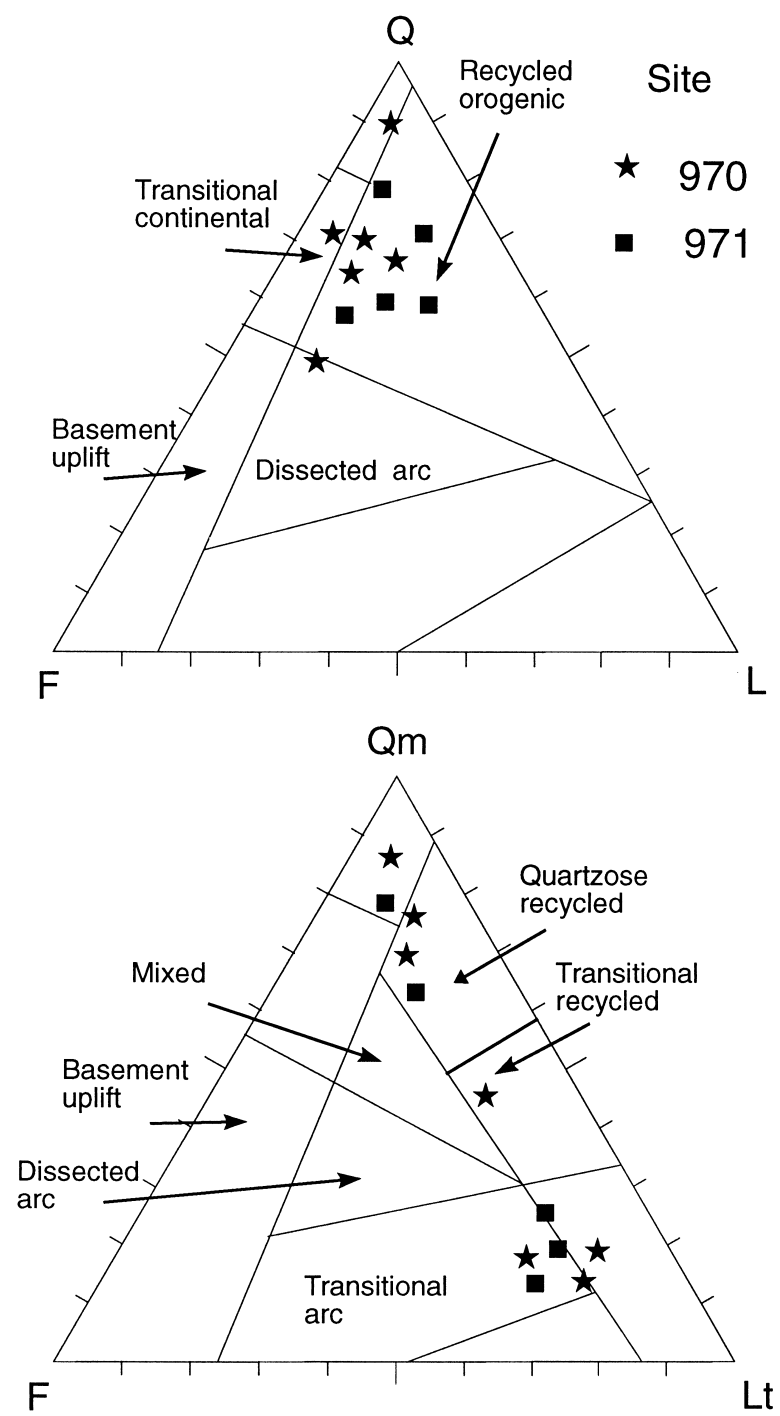

Figure 4. Ternary plots of QFL (top) and QmFLt (bottom), following Dickinson and Suzcek (1979), illustrate the composition and provenance of sandstones from the Milano (Site 970) and Napoli (Site 971) mud volcanoes. See text for abbreviations and explanation.

present. Interstitial (primary) matrix is volumetrically minor and is composed of clay and silt. Another similar siltstone (Sample 160970C-1H-2, 1-3 cm) also contains rare grains of altered basic volcanic rock, rare glauconite, and a minor micritic matrix that is partly recrystallized to microspar. No planktonic foraminifers were observed in this sample, which is correlated compositionally with the lithic sandstones described above.

\section{Fine-Grained Carbonates}

Clasts of pelagic carbonate are present in the mud breccias at both mud volcanoes (Pl. 3). Samples are composed of planktonic foraminifers (e.g., Globigerina sp.) scattered throughout a homogeneous, micritic matrix (Samples 160-971A-6X-1, 34-36 cm, 971A-6X-CC, 0$3 \mathrm{~cm}, 971 \mathrm{~B}-22 \mathrm{X}-\mathrm{CC}, 21-23 \mathrm{~cm}, 970 \mathrm{C}-1 \mathrm{H}-1,83-84 \mathrm{~cm}, 970 \mathrm{~A}-1 \mathrm{H}-$ 
4, 65-67 cm, and 970A-5X-CC, 0-2 cm). Locally, the foraminiferal tests are relatively densely packed (Sample 160-970C-1H-3, 119$121 \mathrm{~cm}$ ). Evidence of current reworking (e.g., formation of microcross-lamination) was not observed. Shallow-water carbonate, such as bivalve fragments, and siliciclastic (sediment) components are absent.

\section{Calcarenites with Pelagic Components}

Several mud breccia clasts are composed almost entirely of calcium carbonate. Sample 160-971A-9X-CC, 38-41 cm, is composed almost completely of well-sorted planktonic foraminifer tests set in a micritic matrix (packstone; Pl. 3). Many of the tests are fragmented. Also present are scattered grains of micrite, mudstone microclasts, echinoderm plates and a minor siliciclastic component, made up mainly of scattered, relatively coarse quartz grains, polycrystalline quartz and rare plagioclase (Sample 160-970A-7X-1, 19-22 cm). Other clasts (Sample 160-970D-5H-6, 69-72 cm) include rare benthic foraminifers filled with calcite spar. Another compositionally similar packstone contains glauconite pellets (Samples 160-970C-3H-3, 140-142 cm, and 970A-4X-CC, 25-27 cm).

Several calcarenite clasts of redeposited carbonate contain a significant, but subordinate, proportion of siliciclastic grains (Samples 160-970C-1H-4, 26-30 cm, and 970C-3H-5, 1-3 cm). Such clasts (Sample 160-971A-3H-3, 30-32 cm) contain both shallow-water and pelagic carbonate. The pelagic carbonate comprises numerous planktonic foraminifers and rare micrite lithoclasts that contain planktonic foraminifers. The neritic carbonate has numerous micritic lumps, some of which exhibit textures that suggest a microbial origin, together with rare shell fragments, echinoderm plates and spines, and rare phosphatic grains. In addition, numerous terrigenous grains are composed mainly of angular to subangular quartz, rare polycrystalline quartz, plagioclase, and muscovite (unstrained). The micritic matrix makes up to $10 \%$ of the sediment volume.

Another clast, composed of relatively fine-grained silty limestone (Sample 160-970D-4H-3, 52-54 cm), is dominated by elongate grains composed of shell fragments (mainly bivalves), planktonic foraminifers, and echinoderm plates, as well as rare grains of micrite and phosphatic grains. Scattered terrigenous grains, mainly quartz and muscovite, are also present. The micritic matrix is partly to completely replaced by sparry calcite, along with rhombic carbonate, probably dolomite.

\section{Calcarenites with Shallow-Water Components}

Rare clasts are composed mainly of neritic carbonate, with only subordinate pelagic carbonate and siliciclastic sediment. One clast (Sample 160-970D-3H-6, 42-49 cm) consists of fragments of carbonate (of algal or fungal origin), bivalve shell fragments, fragments of polyzoans (e.g., bryozoans), echinoderm plates and spines, and both planktonic and benthic foraminifers (e.g., miliolines). Terrigenous grains are mainly relatively large subrounded grains of quartz (medium to coarse grained), along with polycrystalline quartz, plagioclase, and perthite. Other lithoclasts are psammitic schist and pelagic carbonate. Glauconite-like grains are scattered throughout.

\section{Mixed Quartzose and Carbonate Clastics}

One unusual clast from the Milano mud volcano (Sample 160970C-5H-3, 84-87 cm) comprises heterogeneous sandy and silty lithoclastic limestone, containing both shallow- and deep-waterderived components ( $\mathrm{Pl} .3$ ). The pelagic component is mainly plank- tonic foraminifers, both whole and intact. The shallow-water-derived component includes bivalve shell fragments, benthic foraminifers, and echinoderm plates and spines. The matrix is copious and partly recrystallized. Lithoclasts are commonly psammitic schist, quartzose and micaceous, along with rounded fragments of serpentinite, altered basic volcanics, radiolarite (showing various degrees of recrystallization), mudstones, micrite, micrite with planktonic foraminifers, partly recrystallized micrite, partly recrystallized quartzose siltstone, and recrystallized limestone (marble). Individual grains include quartz, plagioclase, muscovite, apatite, zircon, and spinel. This sample is correlated with the relatively rare lithic sandstone and unusual siltstone that includes basic volcanic rock clasts, described earlier.

\section{Shardlike Clasts}

The claystone clasts have a microplaty or microbreccia-like appearance in places, and locally show a "jigsaw-puzzle" texture. The platy texture is defined by linear, to locally rectilinear, narrow, elongate, parallel-sided voids. In some areas, the claystone and the intervening voids are cut by tiny cracks, some nearly at right angles (Pl. 4), which are locally healed with calcite cement (Sample 160-971B$6 \mathrm{X}-1,50-51 \mathrm{~cm})$. Similar features are common in the clay matrix and are described in more detail below.

Some of the poorly consolidated claystones also exhibit a lamination that differs from the typical primary lamination as it is variable and anastomosing on a small scale; the texture is referred to as a pseudolamination (Pl. 4; Sample 160-970D-1H-3, 130-132 cm). The pseudolamination is locally cut at a high angle by veinlets that are now empty (Pl. 4). In one case, the pseudolamination was seen to be deformed against hard, cigar-shaped pyrite (probably a pyritized burrow); this shows that the lamination developed after the diagenetic formation of pyrite. In some cases, elongate parallel-sided voids also occur within clay clasts (Sample 160-970C-3H-2, 19-21 cm; Pl. 5). Some claystone clasts have split to form elongate, shardlike fragments. Locally, all transitions are visible between intact pseudolaminated claystone intraclasts, partly detached clay fragments, wholly detached fragments in proximity (locally with a jigsaw-puzzle textures), and individual elongate fragments isolated within the matrix.

\section{Matrix}

Petrographic study of the matrix reveals evidence of (1) unresolvable fine-grained clay and mud, (2) weakly consolidated clay and mud that are compositionally similar to poorly consolidated claystone and mudstone clasts discussed in the previous section, (3) welllithified sediment that can be correlated with the compositions of the better lithified clasts, also discussed previously.

Impregnated thin sections were studied from the Napoli mud volcano (Samples 971A-4H-3, 47-49 cm, 971A-7X-1, 32-35 cm, and 971B-14X-2, 50-52 cm) and from the Milano mud volcano (Samples 970A-14X-1, 46-49 cm, 970D-1H-3, 130-132 cm, 970C-3H-2, 19$21 \mathrm{~cm}$, and $970 \mathrm{C}-3 \mathrm{H}-3,119-121 \mathrm{~cm})$. In addition, the surface texture of the mud matrix was examined using SEM (Fig. 5).

\section{Fine-Grained Sediment}

Fine-grained sediment is mainly clay and mud with minute grains (sericite) that cannot be resolved optically. Additional fine-grained material includes impure micrite, calcareous clay, and fine silt (Sample 160-971B-14X-2, 50-52 cm). No obvious systematic differences were noted between the fine-grained matrix of the Milano and Napoli mud volcanoes. 


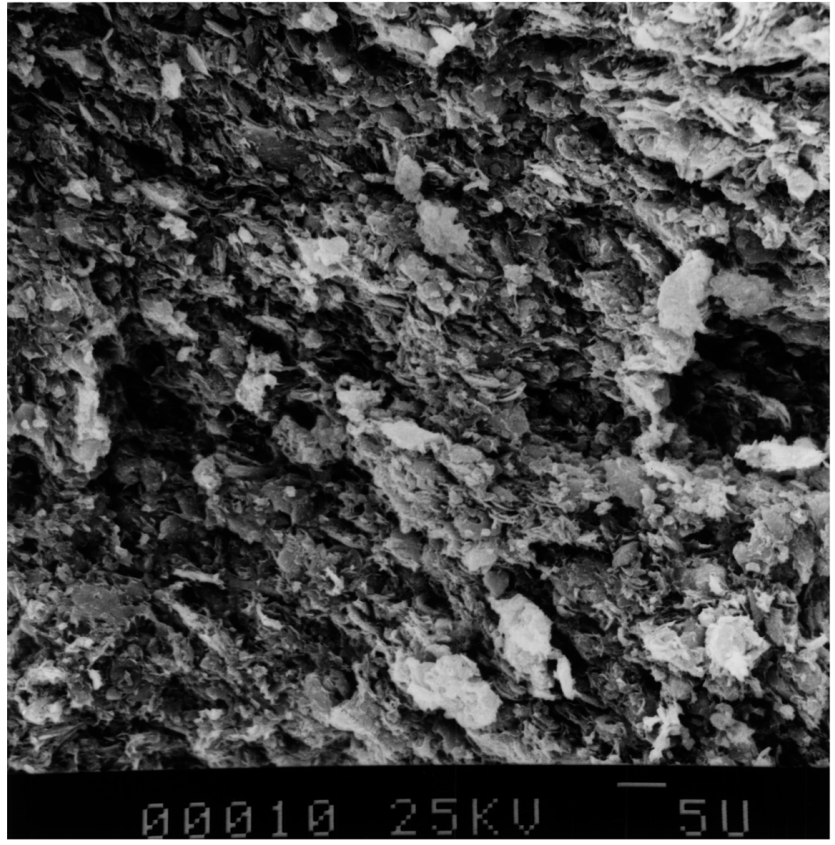

Figure 5. SEM photomicrograph showing the typical texture of undeformed mud breccia matrix (Sample 160-971B-16X-3, 119-139 cm).

\section{Claystone and Mudstone Grains}

All the matrix sediments contain numerous small, $<2$-mm-grains of weakly consolidated claystone and mudstone. These grains are mainly homogeneous and do not include admixed quartzose silt or other material. Many of these clasts are elongate or subrounded to rounded. Some exhibit finely parallel lamination, some of which is assumed to be of primary origin. Pseudolaminated and shardlike grains, similar to those described above, are common.

\section{Siliciclastic and Carbonate Grains}

Siliciclastic grains are scattered throughout the matrix. Many of the quartz grains are relatively large (medium to coarse sand sized), clear, unstrained, and subrounded, to locally well rounded (Sample 160-971A-7X-1, 32-35 cm). Other terrigenous grains are rare plagioclase (locally fresh), perthite, microcline, muscovite, biotite (locally foliated), augite, and hornblende (rare). Scattered planktonic foraminifers (some broken), rare benthic foraminifers, and glauconite pellets were also observed. Large, well-rounded, quartz grains were seen rarely in the sandstone clasts, as described previously.

"Outsize grains," > $2 \mathrm{~mm}$, of quartzose silt with a sparry calcite cement were noted rarely (Sample 160-971A-7X-1, 32-35 cm). Micritic limestone grains are also present in all the matrix samples studied. Some of these are completely homogeneous, whereas others contain scattered planktonic foraminifers, or terrigenous grains (mainly quartz). The micrite grains are generally angular to subrounded (Sample 160-970C-3H-2, 19-21 cm). Numerous angular grains were locally seen defining a jigsaw-puzzle texture (Sample 160-971A-4H$3,47-49 \mathrm{~cm}$ ). Other carbonate grains are recrystallized limestone and coarse-grained limestone, calcarenite, with scattered quartz grains. Rare grains of clay-rich micrite contain scattered quartz grains. Grains of recrystallized limestone and crystalline carbonate (marble) are also locally present (Sample 160-970D-1H-3, 130-132 cm). Other grains include radiolarian chert and polycrystalline quartz.

\section{Lower Clay-Rich Clastics}

The lowermost part of the drilled succession of the Milano mud volcano (about 155-190 mbsf in Hole 970A) includes graded clastic sediments (up to rudite grade) interbedded with fine-grained unconsolidated clay-rich sediment (Fig. 3). These graded units are interpreted as debris flows and both high- and low-density turbidites that developed during the earlier stages of mud volcanism (Emeis, Robertson, Richter, et al., 1996).

Several impregnated thin sections were studied from graded units (Samples 970A-19X-2, 73-77 cm, 970A-19X-2, 84-90 cm, and Sample 160-970A-19X-2, 77-83 cm). Sample 160-970A-19X-2, $73-77 \mathrm{~cm}$, is composed of two units: the first unit is graded silt, and the second is matrix-supported clay-rich sediment. The graded silt consists mainly of quartz and micritic grains. The matrix-supported interval is packed with clay intraclasts, along with a few clasts of homogeneous micrite as well as micrite with planktonic foraminifer tests, partly recrystallized micrite intraclasts, scattered quartz grains, and planktonic foraminifers. The clay clasts are finely laminated and usually rich in fine, disseminated pyrite. No preferred orientation of laminae was observed within individual mud clasts. Most mud clasts are subangular to subrounded. As in most of the mud volcano clay material, the pseudolamination is marked by elongate rectilinear voids, together with shardlike clasts and grains. Scattered grains include quartz, quartzite, planktonic foraminifers (filled with sparry calcite), muscovite, and polycrystalline (metamorphic) quartz. Many of the individual quartz grains are unusually large and well rounded (Sample 160-970A-19X-2, 84-90 cm). Sample 160-970A-19X-2, $77-83 \mathrm{~cm}$, also contains microclasts of microspar, micrite with echinoderm spines, and calcareous siltstone. A large, $\sim 5-\mathrm{mm}$ clast of calcareous sandstone contains grains of radiolarian chert, basic volcanic rocks, serpentinite, monocrystalline and polycrystalline quartz, micrite, muscovite, and plagioclase.

\section{Distal Mud Volcanic Sediments}

Hemipelagic sediments of late Pleistocene age flanking the Milano mud volcano (Hole 970B) include thin (up to several centimeterthick) partings composed of graded silt (Sample 160-970B-5H-1, 32-34 cm; Fig. 3).

Unlike the clasts, the matrix in impregnated thin sections (Milano mud volcano) is revealed to be invariably very poorly sorted (e.g., Sample 160-971B-4H-3, 47-49 cm). It is composed of heterogeneous, well- to poorly lithified clasts in a fine-grained matrix that typically includes scattered silt- to medium-sand-sized terrigenous grains (mainly quartz). The grain size commonly differs markedly in different parts of a single thin section (Sample 160-971B-14X-2, 50$52 \mathrm{~cm}$ ). The individual components of the matrix sediments show no additional features relative to the clasts (see above). The matrix is unconsolidated and shows no evidence of any diagenetic cement development.

\section{Associated Hemipelagic Sediments}

Hemipelagic sediments are present on the outer flanks of the Milano mud volcano (Hole 970B), apparently beyond the maximum dispersal zone of erupted mud debris flows (Emeis, Robertson, Richter, et al., 1996). These hemipelagic sediments contain scattered silty partings, three of which were studied using impregnated thin sections. The stratigraphically lowest of these (Sample 160-970B-5-1, $32-34 \mathrm{~cm}$ ) shows excellent grading, from mixed siliciclastic-carbonate silt to clay. The coarser grained portion comprises quartz, planktonic foraminifers, plagioclase, muscovite, and numerous small, rounded, clay intraclasts, set in a clay-rich matrix, with common pyrite. The finer grained portion is composed of uniform clays, with the 
addition of tiny pyrite framboids, silt grains, and scattered planktonic foraminifers. Samples 970B-1H-2, 113-115 cm, and 970B-1H-2, $129-131 \mathrm{~cm}$, from higher in the section are composed of material that is compositionally similar to the mud volcano matrix, but also contains several clay clasts and pellets. Many of the clay clasts are finely laminated (pseudolaminated?), and include narrow linear voids and elongate mud slivers, or "shards." These small-scale textures and structures are unlikely to have formed by normal hemipelagic deposition, but instead occur as grains that were redeposited by gravity flow from the adjacent mud volcano.

\section{XRD ANALYSIS Napoli Mud Volcano (Site 971)}

The results of whole-rock analysis of the matrix are listed in Tables 1 and 2. Differential thermal analysis and glycolation of selected samples are presented in Table 3.

\section{Hole 971A (Flank Area)}

Calcite and quartz are the most abundant minerals in 17 samples analyzed of the matrix of the mud breccias. Kaolinite is present in all samples. Albite was detected in all samples and is relatively abundant in three samples from Core 160-971B-4H. Muscovite was detected in 12 of the 17 samples. Smectite was recognized in 15 samples, and its identification was confirmed by analysis of the fine fraction. A mineral identified as ankerite, or a complex carbonate (see the following), is present in all 17 samples, and pyrite is in all but one of them (the highest in the sequence, Sample 160-971A-1H, 57-59 cm). Magnesium-rich calcite was also detected in Sample 160-971A-1H, $72-74 \mathrm{~cm}$.

\section{Hole $971 B$ (Outer Flank Site)}

Compositions are similar to Hole 971A in all 31 samples analyzed, as listed in Tables 1 and 2. Samples from Core 160-971B-3H are similar in composition, and quartz and calcite are dominant. Ankerite is unusually abundant in three samples and is detectable in all but two of 12 samples from Core 160-971B-3H. All of these contain detectable kaolinite. Smectite is ubiquitous. Magnesian calcite is present in Samples 971B-3H, CC, 119-121 cm, and 971B-3H, 133$135 \mathrm{~cm}$. Muscovite and albite were also noted in all samples from Core 971B-3H. Samples from Core 971B-4H show a similar pattern. Sample 160-971B-4H-1, 88-90 cm, is unusually rich in ankerite. Samples from lower in this hole (Cores 971B-13X through 20X) show little mineralogical variation. Samples from Cores 160-971B13X through 20X have high halite contents, presumably representing evaporite of assumed Messinian age that was detected in the pore waters (Emeis, Robertson, Richter, et al., 1996).

\section{Hole $971 D$ (Crestal Location)}

Fifty samples were analyzed; all are similar and contain abundant quartz and calcite, and variable amounts of ankerite, kaolinite, pyrite, albite, and muscovite. Smectite is present in all samples above 25 mbsf. Ankerite was noted in all but one sample. Muscovite, present in only 20 out of the 50 samples analyzed, is relatively poorly represented.

\section{Hole 971 (Crestal Location)}

The 20 samples analyzed showed no systematic variation. Analcite and kaolinite are again ubiquitous. Although smectite was not identified by whole-rock XRD, its presence was confirmed by glyco- lation (Table 3). Albite was detected in all but one sample. Highmagnesium calcite was noted in Sample 160-971-1H, 46-48 cm. A soft, pale lump of material was determined to be aragonite (Sample 160-971-1H-4, 95-97 cm).

\section{Milano Mud Volcano (Site 970)}

Thirty-five samples were analyzed from the Milano mud volcano (Site 970), as follows.

\section{Hole 970A (Flank Site)}

Quartz dominates most of the samples analyzed, whereas calcite is more abundant in a few. Kaolinite was detected in all but one sample. Dolomite is present in six samples; analcite was detected in one sample, and pyrite in another. Smectite was not specifically detected by whole-rock XRD, but glycolation confirmed its presence (Table 3).

\section{Holes 970C and 970D (Crestal Locations)}

Samples from Hole 970C are similar in composition to those from the flank site, Hole 970A. Samples from Hole 970D include dolomite in two samples and ankerite in one sample. The ankerite is a minor constituent of one sample and a trace constituent of six others.

\section{DIAGENESIS}

The clasts commonly retain primary depositional textures and fabrics. No evidence of strong compaction (distortion of planktonic foraminifer tests) is observed. Delicate structures, such as thin foraminifer tests within pelagic carbonate, typically remain free of cement and show no evidence of internal collapse. It is thus unlikely that clast lithologies were subjected to strong shearing, either before or during mud volcanism. In addition, pressure solution (stylolite development) was noted only in Sample 160-971B-6X-1, 50-51 cm.

Diagenesis in the quartzose sandstones is marked by partial recrystallization of the minor micritic matrix. Where present, benthic foraminifers remain empty or contain only minor volumes of sparry calcite cement (Sample 160-970C-5H-3, 84-87 cm). In Sample 160970A-11X-CC, 9-10 cm, sparry calcite cement is more extensive and shows optical continuity. This sandstone exhibited a relatively high primary porosity and underwent little compaction before cementation.

A quartzose siltstone in Sample 160-970C-3H-2, 58-62 cm, contains numerous small carbonate rhombs, interpreted as dolomite, both in the matrix and within bioclasts, together with calcareous lithoclasts.

Planktonic foraminiferal tests in the mainly pelagic redeposited limestones (Samples 971-3H-3, 30-32 cm, and 971A-9X-CC, 38-41 $\mathrm{cm})$ are commonly filled with sparry calcite, or disseminated pyrite (Pl. 3). Disseminated pyrite is also common in the matrix and locally within planktonic foraminifer tests (Sample 160-970C-1H-1, 83-84 $\mathrm{cm})$. One clast in Sample 160-970C-3H-3, 140-142 cm, contains numerous small carbonate rhombs. In Sample 160-970A-2H-1, 25-29 $\mathrm{cm}$, several grains are coated with very fine fibrous carbonate, interpreted as a remnant of an early marine cement, originally composed of aragonite or high-magnesian carbonate. Massive fibrous calcite, presumably an authigenic vein filling ( $>1 \mathrm{~cm}$ wide), was observed in one sample (Sample 160-71A-3H-3, 110-113 cm; Pl. 5). The packstones contain numerous planktonic foraminifer tests that are variably filled with sparry calcite. In one clast in Sample 160-970A-10X$1,63-68 \mathrm{~cm}$, the packstone shows evidence of slightly more advanced recrystallization to microspar and rhombic spar (Pl. 3). Plank- 
Table 1. Results of whole-rock X-ray diffraction of matrix samples from the Milano and Napoli mud volcanoes, carried out at the Grant Institute, University of Edinburgh.

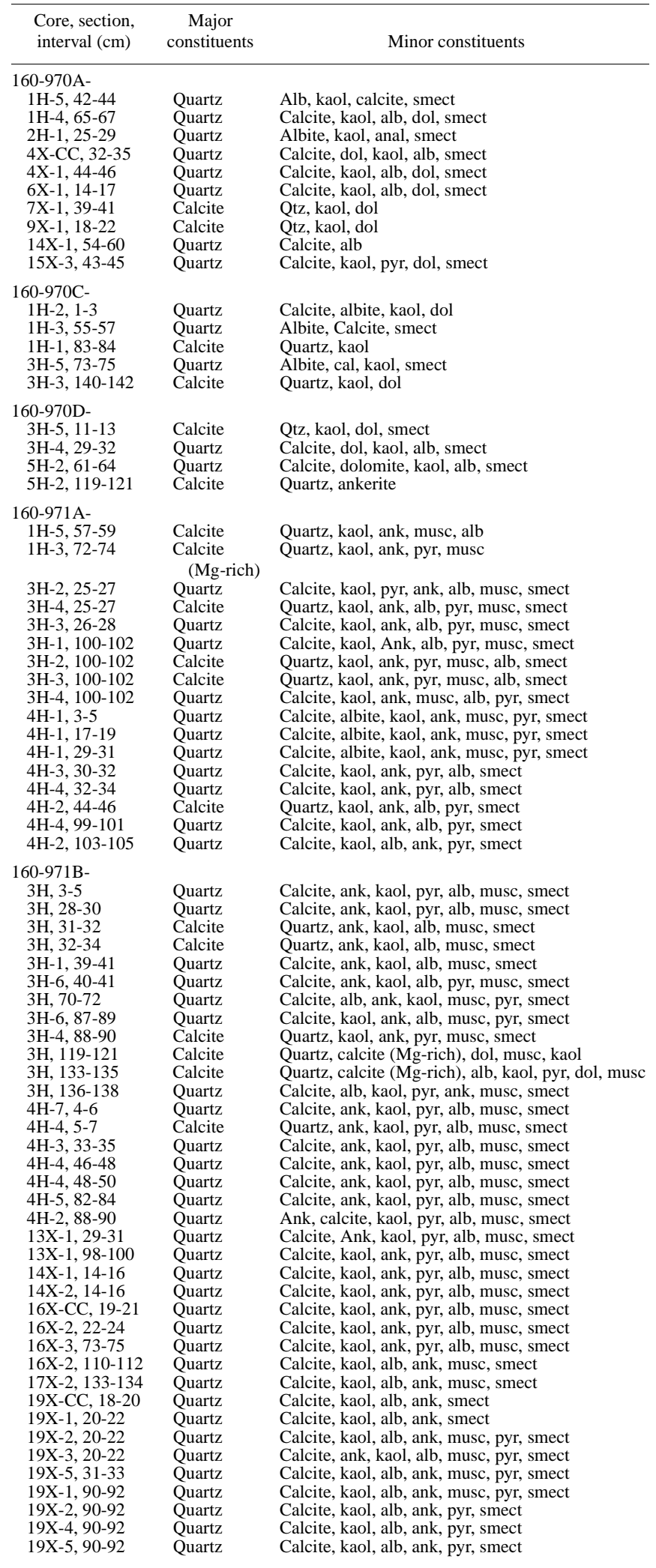

\begin{tabular}{|c|c|c|}
\hline $\begin{array}{l}\text { Core, section, } \\
\text { interval }(\mathrm{cm})\end{array}$ & $\begin{array}{c}\text { Major } \\
\text { constituents }\end{array}$ & Minor constituents \\
\hline $20 X-1,53-55$ & Quartz & Calcite, kaol, alb, ank, pyr, smect \\
\hline $20 X-2,55-57$ & Quartz & Calcite, kaol, alb, ank, pyr, smect \\
\hline $20 \mathrm{X}-2,122-124$ & Quartz & Calcite, kaol, alb, ank, pyr, smect \\
\hline \multicolumn{3}{|l|}{ 160-971D- } \\
\hline $1 \mathrm{H}-5,3-5$ & Calcite & Quartz, ank, kaol, pyr, alb, anal, smect \\
\hline $1 \mathrm{H}-\mathrm{CC}, 11-13$ & Quartz & Calcite, ank, kaol, pyr, alb, anal, smect \\
\hline $1 \mathrm{H}-6,16-18$ & Quartz & Calcite, ank, kaol, pyr, alb, anal, smect \\
\hline $1 \mathrm{H}-4,24-26$ & Calcite & Quartz, ank, kaol, pyr, alb, anal, smect \\
\hline $1 \mathrm{H}-2,45-47$ & Quartz & Calcite, ank, kaol, pyr, alb, anal, smect \\
\hline $1 \mathrm{H}-5,45-47$ & Quartz & Calcite, ank, kaol, pyr, alb, anal, smect \\
\hline $1 \mathrm{H}-1,104-106$ & Calcite & Quartz, alb, kaol, ank, pyr, smect \\
\hline $1 \mathrm{H}-5,110-112$ & Quartz & Calcite, ank, kaol, anal, alb, pyr, smect \\
\hline $1 \mathrm{H}-1,126-128$ & Calcite & Quartz, ank, kaol, anal, alb, pyr, smect \\
\hline $2 \mathrm{H}-5,18-20$ & Quartz & Calcite, ank, kaol, anal, alb, pyr, smect \\
\hline $2 \mathrm{H}-2,19-21$ & Calcite & Quartz, ank, kaol, anal, alb, pyr, smect \\
\hline $2 \mathrm{H}-6,19-21$ & Quartz & Calcite, ank, kaol, anal, alb, pyr, smect \\
\hline $2 \mathrm{H}-1,98-100$ & Calcite & Quartz, ank, kaol, anal, alb, pyr, smect \\
\hline $2 \mathrm{H}-2,98-100$ & Quartz & Calcite, ank, kaol, anal, alb, pyr, smect \\
\hline $2 \mathrm{H}-4,119-121$ & Quartz & Calcite, ank, kaol, anal, alb, pyr, smect \\
\hline $2 \mathrm{H}-3,120-122$ & Calcite & Quartz, ank, kaol, anal, alb, pyr, smect \\
\hline $2 \mathrm{H}-5,120-122$ & Quartz & Calcite, ank, kaol, anal, alb, pyr, smect \\
\hline $2 \mathrm{H}-6,120-122$ & Calcite & Quartz, ank, kaol, anal, alb, pyr, smect \\
\hline $3 \mathrm{H}-2,29-31$ & Quartz & Calcite, ank, kaol, anal, pyr, musc, smect \\
\hline $3 \mathrm{H}-4,29-31$ & Quartz & Calcite, ank, kaol, anal, pyr, musc, smect \\
\hline $3 \mathrm{H}-5,29-31$ & Quartz & Calcite, ank, kaol, anal, pyr, musc, smect \\
\hline $3 \mathrm{H}-7,29-31$ & Calcite & Quartz, ank, kaol, anal, pyr, musc, smect \\
\hline $3 \mathrm{H}-1,100-102$ & Calcite & Quartz, ank, kaol, anal, pyr, musc, smect \\
\hline $3 \mathrm{H}-2,100-102$ & Calcite & Quartz, ank, kaol, anal, pyr, musc, smect \\
\hline $3 \mathrm{H}-3,100-102$ & Calcite & Quartz, ank, kaol, anal, pyr, musc, smect \\
\hline $3 \mathrm{H}-4,100-102$ & Calcite & Quartz, ank, kaol, anal, pyr, musc, smect \\
\hline $3 \mathrm{H}-5,100-102$ & Quartz & Calcite, ank, kaol, anal, pyr, musc, smect \\
\hline $3 \mathrm{H}-6,100-102$ & Quartz & Calcite, ank, kaol, anal, pyr, musc, smect \\
\hline $4 \mathrm{H}-\mathrm{CC}, 15-17$ & Quartz & Calcite, ank, kaol, anal, alb, pyr, musc \\
\hline $4 \mathrm{H}-2,20-22$ & Calcite & Quartz, ank, kaol, anal, alb, pyr, musc \\
\hline $4 \mathrm{H}-3,20-22$ & Quartz & Calcite, ank, kaol, anal, alb, pyr, musc \\
\hline $4 \mathrm{H}-4,20-22$ & Calcite & Quartz, ank, kaol, anal, alb, pyr, musc \\
\hline $4 \mathrm{H}-6,20-22$ & Calcite & Quartz, ank, kaol, anal, alb, pyr, musc \\
\hline $4 \mathrm{H}-7,20-22$ & Quartz & Calcite, ank, anal, kaol, alb, pyr, musc \\
\hline $4 \mathrm{H}-1,38-40$ & Quartz & Calcite, ank, kaol, anal, alb, pyr \\
\hline $4 \mathrm{H}-2,110-112$ & Quartz & Calcite, ank, kaol, anal, alb, pyr, musc \\
\hline $4 \mathrm{H}-4,110-112$ & Quartz & Calcite, ank, kaol, anal, alb, pyr, musc \\
\hline $4 \mathrm{H}-5,110-112$ & Quartz & Calcite, ank, kaol, anal, alb, pyr, musc \\
\hline $4 \mathrm{H}-6,110-112$ & Quartz & Calcite, ank, alb, kaol, anal, pyr, musc \\
\hline $5 \mathrm{H}-2,20-22$ & Quartz & Calcite, ank, alb, kaol, anal, pyr, musc \\
\hline $5 \mathrm{H}-6,26-28$ & Quartz & Calcite, ank, kaol, alb, anal, pyr, musc \\
\hline $5 \mathrm{H}-1,30-32$ & Calcite & Quartz, ank, kaol, anal, alb, pyr, musc \\
\hline $5 \mathrm{H}-3,30-32$ & Quartz & Calcite, ank, kaol, anal, alb, pyr, musc \\
\hline $5 \mathrm{H}-5,30-32$ & Quartz & Calcite, ank, kaol, anal, alb, pyr, musc \\
\hline $5 \mathrm{H}-7,38-40$ & Quartz & Calcite, ank, kaol, alb, anal, pyr, musc \\
\hline $5 \mathrm{H}-6,92-97$ & Quartz & Calcite, ank, kaol, alb, anal, pyr, musc \\
\hline $5 \mathrm{H}-6,110-112$ & Quartz & Calcite, ank, kaol, alb, anal, pyr, musc \\
\hline $5 \mathrm{H}-3,120-122$ & Quartz & Calcite, ank, kaol, anal, alb, pyr, musc \\
\hline $5 \mathrm{H}-4,120-122$ & Quartz & Calcite, ank, kaol, anal, alb, pyr, musc \\
\hline $5 \mathrm{H}-2,130-132$ & Quartz & Calcite, ank, kaol, anal, alb, pyr, musc \\
\hline \multicolumn{3}{|l|}{ 160-971E- } \\
\hline $1 \mathrm{H}-1,14-16$ & Quartz & Calcite, ank, kaol, anal, alb, pyr \\
\hline $1 \mathrm{H}-5,14-16$ & Quartz & Calcite, ank, kaol, anal, alb, pyr \\
\hline $1 \mathrm{H}-7,14-16$ & Calcite & Quartz, ank, kaol, anal, alb, pyr \\
\hline $1 \mathrm{H}-6,18-20$ & Calcite & Quartz, ank, kaol, anal, alb, pyr \\
\hline $1 \mathrm{H}-4,46-48$ & Quartz & Arag, calcite (Mg-rich), calcite ank, kaol, anal, pyr \\
\hline $1 \mathrm{H}-1,95-97$ & Quartz & Ank, calcite, kaol, anal, alb, pyr \\
\hline $1 \mathrm{H}-2,95-97$ & Quartz & Calcite, ank, kaol, anal, alb, pyr, musc \\
\hline $1 \mathrm{H}-3,95-97$ & Quartz & Calcite, ank, kaol, anal, alb, pyr, musc \\
\hline $1 \mathrm{H}-4,95-97$ & Arag & Calcite, quartz, kaol, anal, alb, pyr, musc \\
\hline $1 \mathrm{H}-5,95-97$ & Quartz & Calcite, ank, kaol, anal, alb, pyr, musc \\
\hline $1 \mathrm{H}-6,95-97$ & Calcite & Quartz, ank, kaol, anal, alb, pyr, musc \\
\hline $2 \mathrm{H}-1,35-37$ & Calcite & Quartz, ank, kaol, anal, alb, pyr, musc \\
\hline $2 \mathrm{H}-2,35-37$ & Calcite & Quartz, ank, kaol, anal, alb, pyr, musc \\
\hline $2 \mathrm{H}-3,35-37$ & Quartz & Calcite, ank, kaol, anal, alb, pyr, musc \\
\hline $2 \mathrm{H}-5,35-37$ & Calcite & Quartz, ank, kaol, anal, alb, pyr, musc \\
\hline $2 \mathrm{H}-6,35-37$ & Quartz & Calcite, ank, kaol, anal, alb, pyr, musc \\
\hline $2 \mathrm{H}-1,124-126$ & Quartz & Calcite, ank, kaol, anal, alb, pyr, musc \\
\hline $2 \mathrm{H}-6,132-134$ & Quartz & Calcite, ank, kaol, anal, alb, pyr, musc \\
\hline $2 \mathrm{H}-2,133-135$ & Quartz & Calcite, ank, kaol, anal, alb, pyr, musc \\
\hline $3 \mathrm{H}-\mathrm{CC}, 18-20$ & Calcite & Quartz, ank, kaol, anal, alb, pyr, musc \\
\hline $3 \mathrm{H}-1,18-20$ & Calcite & Quartz, ank, kaol, anal, alb, pyr, musc \\
\hline $3 \mathrm{H}-2,18-20$ & Quartz & Calcite, ank, kaol, anal, alb, pyr, musc \\
\hline $3 \mathrm{H}-1,117-119$ & Quartz & Calcite, ank, kaol, anal, alb, pyr, musc \\
\hline
\end{tabular}

Note: Ank = ankerite, $\mathrm{kaol}=$ kaolinite, anal $=$ analcite, $\mathrm{alb}=$ albite, $\mathrm{pyr}=$ pyrite, musc $=$ muscovite, arag $=$ aragonite, smect $=$ smectite, calcite $(\mathrm{Mg}$-rich $)=$ high-magnesian calcite. 
Table 2. Results of whole-rock X-ray diffraction of selected additional matrix samples from the Milano mud volcano to show the nature of a $7^{\circ}$ $2 \theta$ peak.

\begin{tabular}{|c|c|c|c|}
\hline $\begin{array}{l}\text { Core, section, } \\
\text { interval }(\mathrm{cm})\end{array}$ & $\begin{array}{c}\text { Major } \\
\text { constituents }\end{array}$ & Minor constituents & $7^{\circ}$ peak \\
\hline \multicolumn{4}{|l|}{ 160-970A- } \\
\hline $5 \mathrm{X}-\mathrm{CC}, 14-8$ & Quartz & Calcite, Kaol, pyr, alb, ank & Broad \\
\hline $14 \mathrm{X}-\mathrm{CC}, 7-11$ & Quartz & Calcite, pyr, alb, ank & Broad \\
\hline $12 X-1,11-15$ & Quartz & Calcite, kaol, pyr, alb, ank & Broad \\
\hline $8 \mathrm{X}-\mathrm{CC}, 15-19$ & Quartz & Calcite, kaol, pyr, alb, ank & Broad \\
\hline $13 \mathrm{X}-\mathrm{CC}, 22-26$ & Quartz & Calcite, kaol, pyr, alb, ank & Broad \\
\hline $3 \mathrm{X}-1,24-28$ & Quartz & Calcite, kaol, pyr, alb, ank & Broad \\
\hline $21 \mathrm{X}-\mathrm{CC}, 29-33$ & Quartz & Calcite, kaol, pyr, alb, ank & Broad \\
\hline $4 X-1,31-35$ & Quartz & Calcite, kaol, pyr, alb & Broad \\
\hline $19 X-1,32-36$ & Quartz & Calcite, ank, kaol, pyr, alb, gypsum & Broad \\
\hline $18 X-3,33-37$ & Quartz & Calcite, ank, kaol, pyr, albite & Broad \\
\hline $10 X-1,37-41$ & Quartz & Calcite, kaol, ank, pyr, alb & Broad \\
\hline $2 \mathrm{H}-2,40-44$ & Quartz & Calcite, kaol, ank, pyr, alb & Broad \\
\hline $20 X-2,41-45$ & Quartz & Calcite, kaol, pyr, alb & Broad \\
\hline $20 X-1,74-78$ & Quartz & Calcite, ank, kaol, pyr, albite & Broad \\
\hline $17 \mathrm{X}-2,86-90$ & Quartz & Calcite, ank, kaol, pyr, alb, musc & Not present \\
\hline $1 \mathrm{H}-2,103-107$ & Quartz & Calcite, kaol, pyr, ank, alb & Broad \\
\hline $15 \mathrm{X}-2,126-130$ & Calcite & Quartz, kaol, pyr, ank, alb & Broad \\
\hline $19 X-1,135-139$ & Quartz & Calcite, kaol, ank, pyr, alb (bassanite?) & Broad \\
\hline $16 \mathrm{X}-2,140-144$ & Calcite & Quartz, ank, kaol, pyr, alb, musc. & Not present \\
\hline \multicolumn{4}{|l|}{ 160-970B- } \\
\hline $3 \mathrm{H}-4,30-34$ & Calcite & Quartz, ank, kaol, alb, musc, halite & Not present \\
\hline $5 \mathrm{H}-4,70-74$ & Calcite & Quartz, ank, kaol, alb, musc, halite & $6.4^{\circ}$ broad \\
\hline $2 \mathrm{H}-4,78-82$ & Calcite & Quartz, ank, kaol, alb, musc, halite & Not present \\
\hline $1 \mathrm{H}-2,95-99$ & Calcite & Quartz, pyr, kaol, arag, ank, alb, halite & Not present \\
\hline $4 \mathrm{H}-4,102-106$ & Calcite & Quartz, pyr, kaol, ank, alb, musc, halite & Not present \\
\hline \multicolumn{4}{|l|}{$160-970 \mathrm{C}-$} \\
\hline $1 \mathrm{H}-\mathrm{CC}, 10-14$ & Quartz & Calcite, kaol, ank, pyr, alb & Broad \\
\hline $2 \mathrm{H}-3,40-44$ & Quartz & Calcite, kaol, Alb, ank, pyr & Broad \\
\hline $3 \mathrm{H}-1,66-70$ & Quartz & Calcite, kaol, pyr, alb, halite & Broad \\
\hline \multicolumn{4}{|l|}{ 160-970D- } \\
\hline $3 \mathrm{H}-4,2-6$ & Quartz & Calcite, kaol, pyr, ank, alb, musc & $5^{\circ}$ peak \\
\hline $2 \mathrm{H}-4,26-30$ & Quartz & Calcite, kaol, pyr, ank, alb & $7^{\circ}$ broad \\
\hline $4 \mathrm{H}-4,26-30$ & Calcite & Quartz, ank, pyr, kaol, alb, arag, halite & Not present \\
\hline $2 \mathrm{H}-2,26-30$ & Quartz & Calcite, kaol, alb, ank, pyr & $7^{\circ}$ broad \\
\hline $1 \mathrm{H}-1,40-44$ & Quartz & Calcite, alb, kaol, ank, musc & $7^{\circ}$ broad \\
\hline $1 \mathrm{H}-2,40-44$ & Quartz & Calcite, kaol, alb, ank, pyr & $7^{\circ}$ broad \\
\hline $5 \mathrm{H}, 94-98$ & Quartz & Calcite, kaol, alb, pyr, ank & $7^{\circ}$ broad \\
\hline
\end{tabular}

Notes: Ank = ankerite $; \mathrm{kaol}=$ kaolinite $;$ anal $=$ analcite $;$ alb $=$ albite $;$ pyr $=$ pyrite $;$ musc $=$ muscovite arag $=$ aragonite $;{ }^{\circ}$ are in $2 \theta$. Analysis made at the Grant Institute, University of Edinburgh

tonic foraminifer shells in the pelagic carbonate are filled with sparry calcite, or are partly to completely empty (Sample 160-971A-6X-1, 34-36 cm; Pl. 3).

Diagenesis in the rare, mainly shallow-water-derived, limestone clasts (e.g., siltstone and mudstone from Sample 160-970D-3H-6, $42-49 \mathrm{~cm}$ ), is marked by the precipitation of calcite spar cement, syntaxial spar overgrowth on echinoderm plates, and the widespread precipitation of disseminated pyrite. Other clasts of fine-grained limestone (Sample 160-970D-4H-3, 52-54 cm) contain some planktonic foraminifers that are almost entirely filled with pyrite.

\section{STRUCTURES WITHIN CLASTS Sedimentary Structures}

The quartzose sandstone clasts (Pl. 4) are typically very well sorted (Sample 160-970D-5H-2, 61-64 cm) and locally show clear evidence of systematic size grading (Sample 160-970A-2H-1, 25-29 $\mathrm{cm})$. In places, cross lamination and small-scale cross bedding were observed in clasts of fine-grained sandstone (Sample 160-970C-1H$5,26-30 \mathrm{~cm}$ ). Parallel or subparallel grain alignment is locally distinguished by grains that are rarely mainly tabular (Sample 160-970A$1 \mathrm{H}-5,42-44 \mathrm{~cm}$ ). Sample 160-970A-2H-1, 25-29 cm, a fine sandstone, was seen to grade into siltstone rich in muscovite, but the overall gradation is interrupted by relatively coarse laminae up to several millimeters thick. The base of this graded unit is sharp, and the basal several millimeters contain numerous tiny $(<1 \mathrm{~mm})$ clay intraclasts.
Table 3. Results of glycolated whole-rock X-ray diffraction of matrix samples from the Milano and Napoli mud volcanoes.

\begin{tabular}{|c|c|c|c|}
\hline $\begin{array}{l}\text { Core, section, } \\
\text { interval }(\mathrm{cm})\end{array}$ & Major constituents & Minor constituents & Trace \\
\hline \multicolumn{4}{|l|}{ 160-970A- } \\
\hline $6 X-1,14-17$ & Quartz, calcite & Kaol, pyr & Alb, ank (halite) \\
\hline Heated at $550^{\circ} \mathrm{C}$ & $\begin{array}{l}\text { Kaol, pyr, ank, and } \\
\text { halite all gone }\end{array}$ & Calcite reduced & Anhydrite formed \\
\hline \multicolumn{4}{|l|}{$160-970 \mathrm{C}-$} \\
\hline $3 \mathrm{H}-5,73-75$ & Quartz & Albite & Pyr, kaol, calcite \\
\hline Heated & $\begin{array}{l}\text { Kaol, pyr, and calcite } \\
\text { all gone }\end{array}$ & & \\
\hline \multicolumn{4}{|l|}{ 160-970D- } \\
\hline $5 \mathrm{H}-2,61-64$ & Quartz, calcite & Kaol, pyr & Alb, ank \\
\hline Heated & Kaol and pyr gone & $\begin{array}{r}\text { Calcite and ank } \\
\text { levels similar }\end{array}$ & Anhydrite (weak) \\
\hline \\
\hline Heated & Kaol and pyr gone & $\begin{array}{l}\text { Calcite and ank } \\
\text { similar }\end{array}$ & Anhydrite formed \\
\hline \\
\hline Heated & Kaol and pyr gone & $\begin{array}{l}\text { Calcite and ank } \\
\text { (reduced) }\end{array}$ & $\begin{array}{l}\text { Anhydrite and } \\
\text { hematite formed }\end{array}$ \\
\hline \multicolumn{4}{|l|}{ 160-971B- } \\
\hline Heated & $\begin{array}{l}\text { Halite gyp, kaol, and } \\
\text { pyr gone }\end{array}$ & $\begin{array}{l}\text { Calcite and ank } \\
\text { reduced }\end{array}$ & $\begin{array}{l}\text { Anhydrite and } \\
\text { hematite formed }\end{array}$ \\
\hline \multicolumn{4}{|l|}{ 160-971D- } \\
\hline Heated & $\begin{array}{l}\text { Kaol, pyr, halite, and } \\
\text { gyp gone }\end{array}$ & & $\begin{array}{l}\text { Anhydrite and } \\
\text { hematite formed }\end{array}$ \\
\hline \multicolumn{4}{|l|}{$160-971 \mathrm{E}-$} \\
\hline $1 \mathrm{H}-2,95-97$ & Quartz, calcite, & Ank & Kaol (halite, gyp) \\
\hline Heated & $\begin{array}{l}\text { Kaol, calc, ank, halite } \\
\text { and gyp all gone }\end{array}$ & & $\begin{array}{l}\text { Anhydrite and } \\
\text { hematite formed }\end{array}$ \\
\hline
\end{tabular}

Notes: All samples were also glycolated. The peak that had been at $7^{\circ} 20 \min (12.5 \AA)$ moved to $5^{\circ} 20 \mathrm{~min}(17 \AA)$, which suggests the presence of Na-rich smectite. In 160 $970 \mathrm{D}-5 \mathrm{H}, 61-64 \mathrm{~cm}$, the above peaks were sharp and, on heating, a peak remained at $6.4^{\circ} 2 \Theta$, unlike the others when it moved to $9^{\circ} 20 \min (10 \AA)$. Ank = ankerite; $\mathrm{kaol}=$ kaolinite $;$ alb $=$ albite; pyr $=$ pyrite $;$ gyp = gypsum

Several limestone clasts also exhibit size grading (Samples 970A$7 \mathrm{X}-1,19-22 \mathrm{~cm}$, and 971B-16X-2, 15-17 cm). For example, one sample of silty limestone (Sample 160-971A-3H-3, 30-32 cm) is dominated by planktonic foraminiferal tests that are extremely well sorted and well graded, and range from medium to fine grain size. The coarser grained portion of the rock is rich in micritic carbonate lithoclasts (about $40 \%$ ) relative to terrigenous components (mainly quartz; about $20 \%$ ) and planktonic foraminifers $(<5 \%)$. By contrast, the finer grained part of the rock contains a much higher abundance of planktonic foraminifers $(\sim 20 \%)$ relative to micritic pellets (about $30 \%$ ) and terrigenous grains (approximately 15\%). A packstone is composed mainly of densely packed planktonic foraminifer tests that are also very well sorted (Sample 160-971A-9X-CC, 38-41 cm). Sample 160-970D-4H-3, 52-54 cm, is mainly composed of elongate bioclasts - shell and foraminifer test fragments-that are aligned to produce well-developed parallel lamination. Such grain alignment is seen in several other clasts (Sample 160-970C-3H-3, 140-142 cm).

\section{Tectonic-Related Structures}

Little or no tectonic deformation was seen within most of the well-lithified clasts (Pl. 4). A clast of packstone contains a vein filled with coarse sparry calcite (Sample 160-970C-3H-5, 1-3 cm). However, in rare cases, quartz grains in sandstones are sheared and fragmented. Locally, microfractures are healed by sparry calcite (Pl. 4). A quartzose sandstone clast is cut by a vein of coarse, sparry calcite in Sample 160-970A-9X-1, 62-65 cm. Also, small clasts of micrite within a sample of matrix from the Milano mud volcano contain a 
network of small anastomosing veinlets that could be of tectonic origin. Pelagic carbonate in Sample 160-970A-1H-4, 65-67 cm, is cut by small anastomosing veins filled with sparry calcite. Several clasts of micrite in the graded claystones of the lower part of the succession in the Milano mud volcano (Hole 970A) contain fine, calcite-filled veins (Sample 160-970A-19X-2, 77-83 cm) that are assumed to relate to deformation that predated the mud volcanism. These veins contrast with small-scale soft-sediment structures (shearing, veining) in soft mud and clay, described below, that are believed to relate to actual mud eruption. As noted previously, one quartzose sandstone is faulted, showing slickensides on the plane of disruption; however, this deformation is thought to have occurred before mud volcanism.

\section{DISCUSSION AND INTERPRETATION Comparisons with Adjacent Regions}

Consideration of possible source areas of the mud volcano sediments must include the regional geological setting.

\section{Possible Southerly Source}

The composition of to Pleistocene to Holocene turbidites from areas south of the Mediterranean Ridge provides clues about the possible provenance of clast lithologies. Modern sands from the Nile cone are composed of rounded, frosted, quartz grains, with clinopyroxene, hornblende, and epidote (Ryan et al., 1973).

The Nile River is also the dominant source of clay minerals in the Eastern Mediterranean Sea today (Ryan, Hsü, et al., 1973). Nilederived clay is characterized by well-crystallized montmorillonite, and contains little illite and very little chlorite. The kaolinite/illite ratio is high in Nile source materials, which suggests that the Nile was the main source of Pleistocene-Holocene clay on the Herodotus abyssal plain (Nesteroff, 1973). The kaolinite is inferred to have formed by weathering of continental terrains (Chamley et al., 1978) and is ubiquitous in sediments derived from both the southern and northern Mediterranean areas (Zemmels and Cook, 1973), although Nesteroff (1973) argued for an origin mainly from the Nile.

Farther west, two types of Pleistocene to Holocene turbidites were recovered in piston cores from the Herodotus abyssal plain southeast of the Olimpi area (Cita et al., 1984). The dark gray, fine sand and silt turbidites are similar to samples from the Milano and Napoli mud volcanoes. The Herodotus sediments contain quartz, plagioclase, mica flakes, hematite, and minor calcite, together with sporadic iron oxides and abundant well-crystallized smectite, kaolinite, and minor illite and chlorite. The pale turbidites are bioclastic and contain bryozoans, echinoid spines, mollusks, larger foraminifers, and less abundant plankton and deep-sea benthic fauna. Compared to the terrigenous turbidites, the fine fraction contains greater amounts of illite and chlorite, but lesser amounts of smectite and a rather constant amount of kaolinite. This indeed mirrors the clay mineralogical composition of the matrix of the mud volcano deposits. Cita et al. (1984) argued that the terrigenous clay-rich turbidites were derived from the Nile. The origin of the calcareous turbidites was less obvious, but supply through submarine canyons on that North African slope is inferred, mainly because the Mediterranean Ridge was assumed to be a topographic barrier to supply from the north. Similar siltstones are also known elsewhere from Miocene successions, especially within the Messinian interval (Site 968, south of Cyprus; Emeis, Robertson, Richter, et al., 1996).

The composition of sands shed from North Africa in the Miocene is known from onshore studies in Libya (Selley, 1969). The coastal Madara Formation is composed of alternating sandstones, limestones, shales, and claystones. The sandstones are composed mainly of quartz, but also contain minor plagioclase, iron ore, epidote, tourmaline, zircon, titanite, rutile, and anatase. Several different types of quartz are present: unstrained with rutile inclusions, unstrained with no inclusions, strained, polycrystalline, and chert. A granitic or granitic gneiss provenance was inferred. The sandstone was assumed ultimately to have been derived from the Precambrian basement of the Sahara, and then to have undergone multicyclic reworking from the early Paleozoic onward. The variety of different quartz types present in the sandstones means that (in terms of composition alone) all the quartzose sandstone clasts from the Napoli and Milano domes could have been derived from different African basement units. However, other evidence, such as the presence of probably ophiolitic grains and the low textural maturity, suggests an alternative source for the more lithic sandstones (see subsequent discussion). The limestones are composed mainly of shell debris, pellets, intraclasts, quartz, micrite, and sparite, with a high primary porosity. The upper Oligocenelower Miocene Nummidian flysch of other parts of North Africa (e.g., in the Maghrebian chain; Flandrin, 1948; Guerra et al., 1992) and in southern Italy and Sicily (Dongarra and Ferla, 1982) is of similar composition. All these deposits are both texturally and chemically mature and were supplied by mainly eolian processes from the Precambrian North African craton; all are similar to many of the mud volcano clasts studied.

\section{Northerly Source}

Provenance from Crete and adjacent areas of the Aegean is a possibility that can be assessed by comparing the composition of Leg 160 sandstone clasts with that of siliciclastic sediments from the Hellenic Trench and the Strabo Trench and with units of southern Crete. Unfortunately, none of the sands recovered from the Hellenic Trench during Deep Sea Drilling Project Leg 13 (Sites 127 and 128) underwent X-ray analysis, but the finer grained sediment contains quartz, chlorite, mica, dolomite, pyrite, and rare palygorskite (Zemmels and Cook, 1973). Sands from the Strabo Trench farther east (Hole 129B) are lithoclastic sandstones (including andesitic volcanics), metamorphic fragments, chert, and mudstones. Most of the clays are rich in chlorite relative to kaolinite, a typical feature of the northeast Mediterranean area. Some of the lithoclastic sandstones studied from the mud volcanoes are similar to these trench sediments.

Comparison can also be made with the onland geology of Crete, which is dominated by a strongly faulted subhorizontal stack of thrust sheets (e.g., Seidel et al., 1982; Hall et al., 1984; Fassoulas et al., 1994; Table 4).

\section{Origin of Clast Lithologies}

We now assess the origins of the mud volcano clasts. Following are the four main types of sedimentary rock, in decreasing order of abundance: (1) claystone and mudstone, (2) siltstone and sandstone, (3) shallow-water carbonate, and (4) deeper water pelagic carbonate. These clasts are assumed to have been derived from host strata beneath the mud volcanoes of mainly or entirely early-middle Miocene age (Emeis, Robertson, Richter, et al., 1996).

\section{Mineralogy and Composition}

The source of the quartzose sandstones was mainly intrusive igneous rock (granodiorite), in view of the common occurrence of plutonic quartz, plagioclase, orthoclase, perthite, augite, and hornblende. However, a subordinate metamorphic gneissic contribution is marked by polycrystalline quartz, psammitic schist, muscovite, and epidote. Minor quantities of both neritic (bivalve shell fragments) and pelagic (planktonic foraminifers) carbonate are also present. 
Table 4. Simplified tectonostratigraphy of the thrust sheets exposed on Crete.

\begin{tabular}{ll}
\hline \multicolumn{1}{c}{ Tectonic unit } & \multicolumn{1}{c}{ Main features } \\
\hline Ophiolites & Little-metamorphosed Jurassic ophiolites and ophiolitic melange \\
Asteroussia & Paleozoic mainly silicic metamorphics; HP/LT Cretaceous metamorphism \\
Vatos-Arvi Miamou & Permian/Jurassic meta-accretionary prism, including ophiolitic melange; Jurassic? HP/LT metamorphism \\
Pindos & Triassic/Eocene unmetamorphosed deep-sea sediments, including limestone and chert \\
Gavroro & Triassic/lower Eocene low-grade, mainly shallow-water carbonates, flysch at top \\
Phyllite-Quartzite & Permian/Triassic siliceous metaclastics, metabasalts, marbles, etc., upper Oligocene-lower Miocene HP/LT metamorphism \\
Plattenkalk & Permian/lower Oligocene, bedded metacarbonates and metaflysch; Oligocene-early Miocene HP/LT metamorphism \\
\hline
\end{tabular}

Note: HP/LT = high pressure - low pressure. (Tectonostratigraphy from Seidel et al., 1982; Hall et al., 1984; Fassoulas et al., 1994). See text for explanation

The volumetrically subordinate heterogeneous lithic sandstones (and compositionally similar siltstones) that include metamorphic quartz (polycrystalline quartz and schist), serpentinite, altered basic volcanic rocks, and radiolarian chert was derived mainly from psammitic (siliceous) metamorphic units (including low-grade metasedimentary rocks), with the addition of material derived from a probable ophiolite-type suite.

A "true" ophiolite comprises an ordered succession of ultramafic and mafic intrusives and basic extrusives. Cherts are typically associated with ophiolites, but are not part of the formal definition. Of the typical ophiolitic lithologies, serpentinite and basic extrusives were observed. Other lithologies (gabbro) were not seen, but could be represented by disaggregated grains (plagioclase, pyroxene, and olivine). Radiolarian chert ranges from unrecrystallized to totally recrystallized clasts and grains. The serpentinite, basic extrusives, and radiolarian cherts can be interpreted as remnants of an ophiolite-related unit, which could include an intact ophiolite, an ophiolitic melange (units formed by dismembering of an intact ophiolite), or an assemblage of units that were not originally derived from a true ophiolite (e.g., a subduction-accretion complex composed of basic extrusives, chert, and some ultramafics).

Some of the clasts were derived from a shallow-water platform carbonate setting. Several are admixed with terrigenous grains of the typical litharenite composition described previously (including wellrounded quartz grains). However, shallow-water carbonate was also found within the contrasting lithic sandstones, including the possible ophiolite-derived material. This suggests that the shallow-water carbonate may have been associated with more than one depositional area.

Some of the pelagic carbonates accumulated away from areas with input of both shallow-water carbonate and terrigenous sediment, presumably in a basinal setting. Other pelagic carbonate, however, is mixed with both the litharenite composition material and shallowwater carbonate. This again suggests the existence of several different areas of pelagic carbonate deposition. Possible depositional pathways and source areas are discussed below.

\section{Depositional Processes}

The sandstone clasts are interpreted as originally turbidites, in view of their well-sorted nature, grading, locally sharp bases, and preferential alignment of tabular grains. Repeated lamination of sand and silt within overall graded units may indicate pulsed turbidity current flow.

Some of the packstones are interpreted as pelagic calciturbidites, admixed with variable quantities of terrigenous sediment. Comparable pelagic calciturbidites are, for example, known onshore from the lower Tertiary to Neogene pelagic carbonate successions of southern Cyprus (Lefkara and Pakhna Formations; Robertson, 1976). The Leg 160 calciturbidites probably formed when pelagic carbonate was reworked from topographic highs into more basinal areas, in some cases becoming mixed with terrigenous sediments.
The pelagic carbonate clasts are interpreted as background pelagic sediments that accumulated in a relatively quiet setting, not greatly affected by currents. Compared to the pelagic calciturbidites, terrigenous material is less abundant, which suggests a relatively distal depositional setting or one isolated from terrigenous input.

\section{Provenance}

Two possible origins for the quartzose sandstones are derivation from the North African continental margin, or from the Eurasian Plate to the north (Crete).

The most obvious sources are due south of the Mediterranean Ridge, from the Cyrenaica Peninsula, or farther east, from the Nile cone. Seismic evidence indicates that during the Neogene, the North African margin formed a seaward-dipping slope (Chaumillon and Mascle, 1995), an ideal setting for accumulation of calcareous pelagic carbonate. A depositional model for the Miocene (pre-Messinian) involving a North African provenance is shown in Figure 6. Mature quartz-rich silts and sands were derived from the continental interior and fed onto the abyssal plain, presumably through submarine canyons. Neritic carbonate accumulated in the coastal area and was transported offshore and mixed to varying extent with the siliciclastic sediment. Pelagic carbonate accumulated on the continental slope and was reworked onto the abyssal plain as calciturbidites, usually with little admixing of neritic carbonate or siliciclastic sediment.

Some of the clasts contain strong indications of a separate provenance, as shown by the presence of probable ophiolite-related material and the different strain history experienced by such lithoclasts. Occurrences of subarkose (Staffini et al., 1993) and subfeldspathic litharenite (Akhmanov, 1996) were noted from several mud volcanoes. Previous XRD studies (Staffini et al., 1993; Akhmanov, 1996) have indicated the local presence of illite and chlorite, for which a northerly origin is likely.

The locally abundant plutonic and metamorphic material in the lithoclastic sandstone clasts was possibly derived from the structurally underlying metamorphic Arvi unit. Limestone lithoclasts that could have been derived from Mesozoic carbonate platform units lower in the thrust stack (Gavrovo unit) are effectively absent. During the late Oligocene and Miocene, the Cretan topography was possibly dominated by large exposures of crystalline metamorphic and plutonic rocks that are now restricted mainly to southern coastal areas (Asteroussia Mountains) following downfaulting and erosion. Deeper levels of the tectono-stratigraphy were only then exposed in the Pliocene-Pleistocene, in response to extensional tectonics that affected the whole South Aegean area (Le Pichon and Angelier, 1979).

The interpretation of a separate northerly provence has several implications: (1) lithoclastic sediment was eroded from high-level units, as exposed in Crete, before dissection by normal faults in the late Miocene onward that exhumed mainly carbonate rocks; (2) the lithoclastic sediments reached the abyssal plain and mixed with African-derived sediment; (3) a well-defined subduction trench possibly did not then exist as a barrier to southward sediment dispersal; (4) al- 


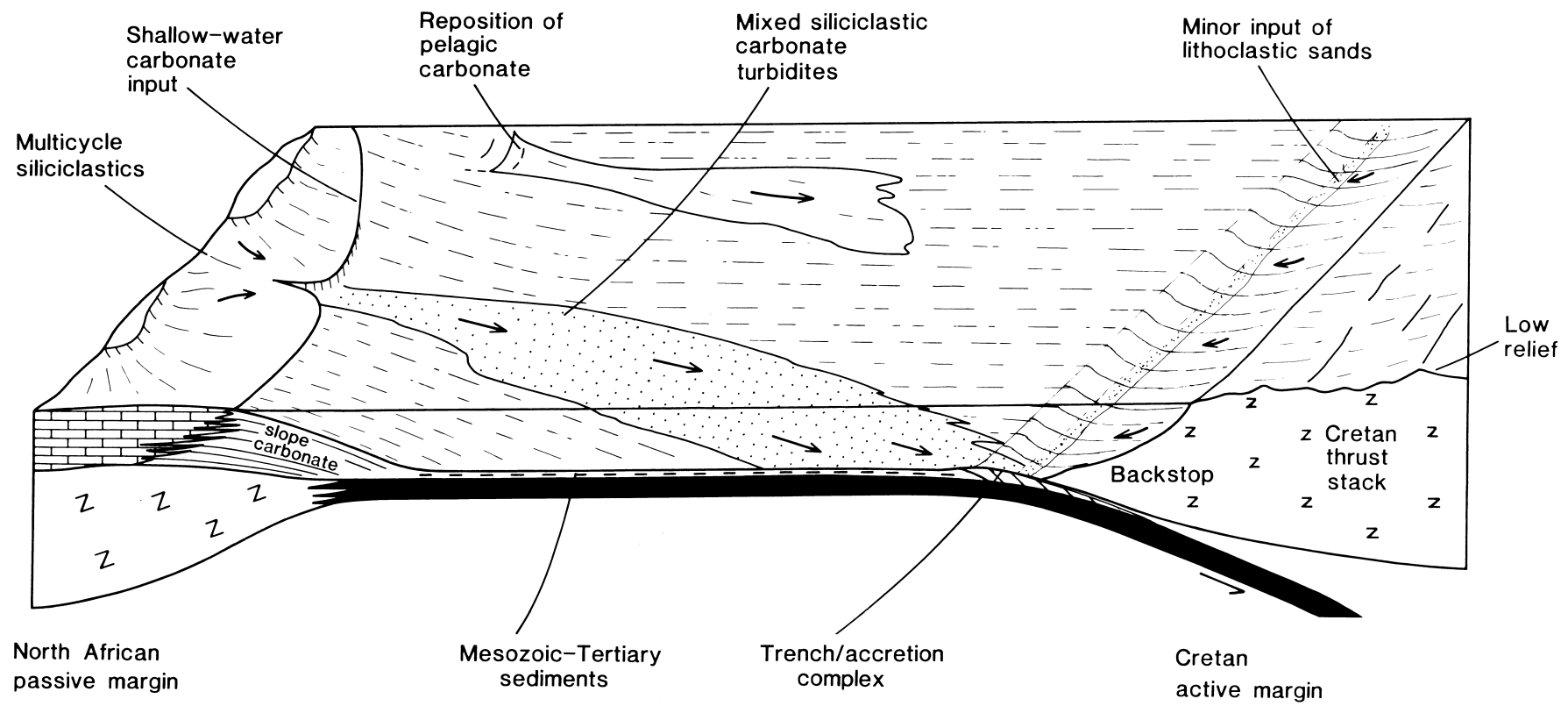

\section{Upper Oligocene/middle Miocene}

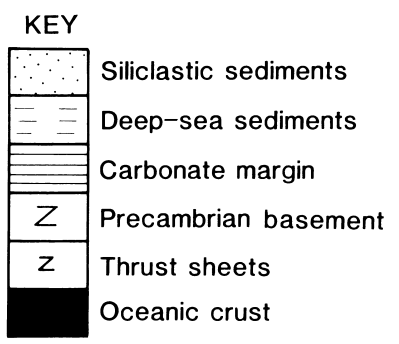

Figure 6. Block diagram showing the inferred depositional setting of sediments that now form clasts within the Milano and Napoli mud volcanoes. The predominant quartz-rich sands and bioclastic carbonates were derived from North Africa. Smectite-rich clays were mostly derived from the Nile River. Smaller volumes of lithoclastic and ophiolite-derived sand were from the north, probably from Crete, or the adjacent south Aegean land mass.

ternatively, the sediments actually accumulated in a subduction trench and were later accreted. Two main factors changed the nature of the Mediterranean Ridge accretionary complex after the Messinian: (1) evaporite was subducted, and (2) collision occurred with North African margin (Kastens, 1981; Chaumillon and Mascle, 1995; Chaumillon et al., in press).

\section{Composition}

\section{Origin of Matrix}

The following statements can be made on the basis of XRD and petrographic analyses: (1) a terrigenous component is ubiquitous (quartz, albite, and muscovite); (2) the main clay mineral present is kaolinite, along with minor sodium-rich smectite; (3) calcite, of detrital and/or diagenetic origin is abundant, and small amounts of magnesian calcite are locally present, of assumed biogenic origin or possibly authigenic origin, and also dolomite; (4) pyrite and ankerite (Ca $\left.\left[\mathrm{Fe}^{2+}, \mathrm{Mg}, \mathrm{Mn}\right]\left[\mathrm{CO}_{3}\right]_{2}\right)$ are common, both together and separately; and (5) analcite is widespread, but only as a minor or trace constituent.

Additional generalizations that can be drawn are that (1) intracore compositional variation is typically as great as variation between cores, and systematic downhole variation was not observed, and (2) the variation between holes within both mud volcanoes is also minimal. One apparent difference is that ankerite is more abundant in the crestal sites compared to the flank site in the Milano mud volcano. Also, muscovite appears to be more abundant in the flank than in one of the crestal sites (Hole 971C). Furthermore, (3) no systematic mineralogical variation exists between the Milano and Napoli mud volcanoes, despite the differences in average grain size of matrix of the two mud volcanoes (Flecker and Kopf, 1996).

\section{Sources of Clay Minerals}

The main source of the smectite (sodium-rich), mixed-layer clays, and kaolinite in the matrix is inferred to be the Nile River. Transmission electron microscopy (TEM) reveals the presence of Fe-Al beidellites, of probable pedogenic origin (Jurado-Rodríguez and Martínez-Ruiz, Chapter 47, this volume).

No marked burial diagenesis of smectite has occurred. The start of breakdown (smectite-to-illite transformation) elsewhere is at temperatures of about $70^{\circ}-96^{\circ} \mathrm{C}$, which is equivalent to $2-3 \mathrm{~km}$ burial at normal geothermal gradients (Hower et al., 1976; Jennings and Thompson, 1986; Whitney, 1990). However, in a low-heat-flow accretionary wedge setting such as the Mediterranean Ridge (Camerlenghi et al., 1995), the depth of initial breakdown could be greater. 
The persistence of smectite is thus compatible with the estimated 5$7 \mathrm{~km}$ depth of the subduction décollement zone beneath the Mediterranean Ridge (Camerlenghi et al., 1995; Schulz et al., 1997).

Illite is minimal in the Mediterranean mud volcano matrix, although it is common in some clasts. Its presence was presumed likely because of erosion of silicic and basic rocks on land around the Mediterranean.

Chlorite was not detected by whole-rock XRD during this study, although we noted traces in XRD analysis of the clay fraction, as confirmed by more sensitive TEM analysis (Jurado-Rodríguez and Martínez-Ruiz, Chapter 47, this volume). Chlorite was reported as locally abundant in some of the other mud volcanoes (Staffini et al., 1993; Akhmanov, 1996). Earlier studies showed that chlorite is particularly abundant in the Messinian interval (Hsü, Montadert, et al., 1978). At Site 375 (Levantine Basin), the upper Tortonian-Messinian includes corrensite, small authigenic dolomite crystals, and flexible attapulgite that was inferred to have formed by orthogenesis in an evaporitic setting (Chamley et al., 1978). The presence of Fe-illite and corrensite in the Eastern Mediterranean could thus fingerprint a diagenetic origin related to desiccating Messinian paleoenvironments, although a detrital origin from Crete is also possible.

\section{Other Minerals}

The zeolite, analcite is widespread in deep-sea calcareous sediments (Berger and von Rad, 1972) and is probably associated with abundant pelagic carbonate clasts. High-magnesian carbonate is assumed to be of biogenic origin (e.g., bivalve shells), and small amounts of fibrous carbonate were indeed noted in thin section. The unique aragonite clast could be a fragment of carbonate cement precipitated from fluids and gases released during mud volcanism. Aragonitic crusts (1-2 cm thick) were also recognized from the Mediterranean mud volcanoes in piston cores (Camerlenghi et al., 1992). Jurado-Rodríguez and Martínez-Ruiz (Chapter 47, this volume) also note the presence of trace amounts of sepiolite and palygorskite using TEM analysis.

\section{Diagenetic Processes \\ Diagenesis of Clast Lithologies}

Glauconite-like pellets form a minor, early diagenetic, component, especially of redeposited carbonates and turbiditic sandstones, and are also present as isolated pellets within the matrix of the mud volcano debris flows. Disseminated framboidal to more coarsely crystalline pyrite is ubiquitous, as confirmed by whole-rock XRD analysis. In one case, a small amount of fibrous calcite is interpreted as an original aragonite or a high-magnesian calcite cement. In several cases magnesian calcite was detected using whole-rock XRD. Sparry calcite cement is widely developed in the matrix and in cavities, especially where significant primary porosity remained after deposition. Fibrous calcite was found as centimeter-thick concretions that formed authigenically. Stylolites, representing sutures where pressure solution occurred, were found within a calcilutite clast (Sample 160-971B-6X-1, 50-51 cm). Recent evidence suggests that, given time, some stylolites may form under subsurface pressure and temperature conditions (Shinn and Robbin, 1983); thus, they are not always reliable indicators of either deep burial or time. From the clast studied, the distinction between stylolite formation in situ (in the source area) or as a result of temporary accretion deep in the wedge before mud extrusion cannot be made.

\section{Diagenesis of Matrix}

As noted above, evidence of burial diagenesis of the clay minerals is scant. However, the ankerite or complex carbonate may be of di- agenetic origin. In marine sedimentary basins, ankerite commonly forms during late diagenesis, under combined lithostatic/hydrostatic loads of several kilometers, in the presence of fluids characterized by light oxygen isotopes, and in some cases, associated with oil migration (Kantorowicz et al., 1987). The main mode of formation is by "ankeritization," in which Fe or Mn substitutes for $\mathrm{Ca}$ or Mg in carbonates.

In the Eocene Wilcox Formation of Texas, a passive-margin setting, ankerite is inferred to have formed at $60^{\circ}-140^{\circ} \mathrm{C}$ and at about $2.5 \mathrm{~km}$ depth (Land and Fisher, 1987). In the Lower Cretaceous Viking Formation of Alberta, ankerite formed at a depth of several kilometers. Meteoric water gained access late in diagenesis, resulting in light stable oxygen isotopic signatures (Longstaffe and Ayalon, 1987). A possible source of the ankeritic carbonate in the Mediterranean Ridge samples is formation during diagenesis at elevated temperature (about $100^{\circ} \mathrm{C}$ ) and moderate depths (about $>1000 \mathrm{mbsf}$ ). Meteoric water might have gained access during the Messinian lowered sea level, as suggested from stable oxygen isotope signatures of both Miocene carbonate clasts and carbonate-bearing mud volcano matrix (from $-5 \%$ PDB and - $1 \%$ PDB; A. Kopf, unpubl. data). Fluids depleted in heavy stable oxygen isotopes might have been involved in ankerite formation.

An alternative interpretation of the XRD signal as stoichiometric ankerite is that it represents complex authigenic carbonate (Kelts and McKenzie, 1982; Tassé and Hesse, 1984). Such carbonates usually have high $\mathrm{Mg}$ contents, but are also rich in $\mathrm{Fe}, \mathrm{Mn}$, and $\mathrm{Ba}$, which can be explained by dissolution of biogenic carbonate (Ca source) and alteration of volcanic rocks, oxides, and hydroxides (Fe, Mn supply; Gieskes and Lawrence, 1981). The Mg content is controlled by clay minerals and their alteration. Similar material has been described from settings comparable to the Mediterranean Ridge (e.g., the Cascadia accretionary prism off Oregon; Kopf et al., 1995). Microprobe studies of nodules and concretions of authigenic carbonate as well as carbonate-cemented silts from the Oregon margin indicate a component of this type of carbonate. Fibrous carbonate, both as entire clasts (3-cm diameter; Sample 160-971A-3H-3, 110-113 cm; Pl. 3) and millimeter-size vein fills, is believed to have formed authigenically during early diagenesis and is comparable to authigenic concretions from Cascadia.

\section{Genesis of Mud Matrix}

We envision two related processes for formation of the mud matrix of both mud volcanoes. The first is derivation of mud from the décollement zone, which was probably located within the Messinian stratigraphic interval. Material from this source was dark, organicrich clay and mud (Schulz et al., 1997), halite (Emeis, Robertson, Richter, et al., 1996), and poorly consolidated quartzose sand (including "outsize," well-rounded grains. The second is derivation of mud and silt from the structurally overlying part of the accretionary wedge of mainly early and middle Miocene age. This includes fine-grained sediment that was originally interbedded with quartzose and calcareous sediments, and fine grains that were generated by abrasion during ascent of the mud magma. Also, all clast lithologies are represented within the matrix as lithoclastic grains, individual minerals, or as bioclasts. Many of the small lithoclastic grains in the matrix simply represent finer equivalents of larger clast lithologies. Pervasive mixing of all these components occurred before and during eruption.

The fine lithoclastic material was derived from essentially the same source units as the clasts: interlayered muds, clays, sands, and limestones. Cementation varied, such that more cemented sandstone and limestone remained as intact clasts, whereas less cemented mud and clay are disaggregated to form a fluidized matrix. Not all the sandstones were originally cemented; many individual quartz grains 
in the matrix are unbroken and have no sparry carbonate cement attached.

The origin of the fine-grained matrix cannot be determined by petrographic studies alone. Several lines of evidence point to an origin within a Messinian interval: (1) clay mineralogy, (2) the presence of low-salinity biota (S. Spezzaferri, pers. comm., 1996), (3) the presence of localized halite clasts in the crestal sediments of the Napoli mud volcano (Emeis, Robertson, Richter, et al., 1996), (4) the mainly terrestrial nature of the organic matter (Schulz et al., 1997), and (5) seismic evidence that the main décollement zone, a possible source of the mud, lies within the Messinian interval (Camerlenghi et al., 1995).

\section{Implication for Mode of Eruption}

The petrographic evidence sheds light on processes of eruption. Four possible origins for the pseudolamination, fracturing, and related void development can be considered: (1) development in the host sediment, before mud volcanism, as a primary lamination; (2) formation related to mud volcanism; (3) development as a result of drilling disturbance (i.e., flushing by seawater), and (4) artificial formation caused by preparation, such as drying or cutting effects.

Of these four, the latter two reasons seem unlikely. An origin by drilling disturbance can be excluded, as similar clay-rich sediments recovered with the same techniques (i.e., advanced piston coring and extended core barrel techniques) have not shown similar textures (Leg 146 clayey silt or silty clay fabrics were rather homogeneous or scaly; Clennell and Maltman, 1995). Concerning sample preparation, air-drying in the sample bags could have affected the initial clay fabric; however, the samples were impregnated immediately after collection. Although some of the initial pore water might have evaporated before impregnation, the observed dismembering of the mudstones cannot be explained by this process. Also, cutting-related genesis can be ruled out because preferred orientation of features is not seen.

Concerning the first two possible explanations of the shardlike textures, it seems unlikely that fragmentation of mudstone created voids of up to about $30 \%$ before resedimentation (in situ) and that such pore space was retained during burial (i.e., subduction-accretion) and extrusion in the mud debris flows. We therefore favor a mechanism related to mud volcanism, as previously described for accretionary prisms (Knipe, 1986; Behrmann, 1991). Dewatering of underconsolidated fine-grained sediments in a compressive environment can trap considerable amounts of overpressured fluid and/or gas that can subsequently give rise to hydrofracturing of muds and mudstones, which increases permeability. This mechanism can trigger fluid escape and may thus be relevant to mud volcanism or mud diapirism. Hydrofracturing can occur in soft sediments in as little as about $100 \mathrm{~m}$ of overburden (Sibson, 1981), as well as deeper in a sedimentary pile. Development of the voids observed could be explained by a fluid-escape mechanism.

Reconstruction of mud volcanism in the Olimpi field suggests that high fluid pressures probably occurred near the beginning of the mud volcanic cycle, with the buildup of cones, as marked by the accumulation of the clay-rich clastic sediments (with common "shards") near the base of the Milano mud volcano succession (Site 970). These matrix-supported clastics were deposited as an apron of debris flows and high-density turbidites (Emeis, Robertson, Richter, et al., 1996; Robertson et al., 1996). Development of such a cone implies that eruption was quite forceful. Thus, the presence of numerous shardlike features, veinlets, and pseudolamination in these gravels could indicate the explosive release of fluid or gas, possibly resulting from a rapid loss of overpressure when eruption took place. Afterward, mud breccias were erupted periodically as debris flows. These may also have been triggered by the buildup of fluid pressure beneath. As demonstrated in the case of the Barbados (Martin et al., 1996) and postulated for the Nankai subduction systems, gas, predominantly methane, follows the subduction trace. This implies that high-pressure fluids derived deep within the subduction zone control the variation in mud volcano activity by variable mobilization and pulsed upward migration (Yassir and Bell, 1994). When the high pressure was rapidly released upon eruption, similar fluid escape features were generated. During final emplacement of the mud flows, shards were perhaps carried passively within the body of the mud debris flow, with little relative motion of clasts and matrix, and hence the excellent preservation of delicate features.

In summary, the pseudolamination is interpreted not as a primary depositional structure, but instead relates to deformation (namely shearing and to the escape of overpressured liquid or gas (causing hydrofracture, etc.) during mud volcanism. Rare anastomosing lamination could relate to shearing, either during detachment from the parent strata, or during mud intrusion or mud extrusion. We hypothesize that increase and then rapid release of fluid pressures within highly impermeable, clay-rich sediment suddenly increased porosity and triggered hydrofracturing, with formation of veins, pseudolamination, and shards.

\section{CONCLUSIONS}

1. Evidence of sedimentary structures indicates that clasts of medium- to coarse-grained sandstones within clasts in the Milano and Napoli mud volcanoes were deposited mainly as turbidites.

2. Two contrasting petrographic sandstone types are present. The most abundant by far is represented by litharenites, containing plutonic and metamorphic quartz, orthoclase and plagioclase feldspar, microcline, and heavy minerals, which together indicate derivation ultimately from the Precambrian basement of North Africa.

3. A volumetrically subordinate type comprises lithic sandstone, with highly strained fragmented quartz grains, schist, basic extrusive rock fragments, serpentinite, and radiolarian chert. This second type is inferred to have been derived from the orogenic belt to the north, possibly from originally emplaced higher thrust sheets on Crete, before extensive erosion and downfaulting as seen today

4. Shallow-water carbonate is mixed with both of these sandstone types, suggesting that carbonate platforms developed in different areas of the Eastern Mediterranean basin during the early-middle Miocene, as indicated by biostratigraphic evidence.

5. Pelagic carbonates accumulated on relative highs and were then reworked basinward by turbidity currents. The main source was possibly a carbonate slope that formed part of the North African passive continental margin.

6. The mud matrix of the debris flows contains highly comminuted material of the same composition of the clasts, although clay and claystone may also be derived from the Messinian interval, on the basis of evidence from other studies.

7. Whole-rock XRD studies of the matrix indicate the presence in most samples of quartz, calcite, kaolinite, and smectite, in generally decreasing order of abundance, together with common muscovite, ankerite (or poorly defined complex carbonate), pyrite, localized analcite and dolomite, and sporadic magnesium-rich calcite and aragonite. Little or no systematic variation in mineralogy is present either vertically or laterally within the individual mud volcanoes or between them, which suggests a consistent composition of source materials. Most of the smectite, mixedlayer clays, and kaolinite were derived from the Nile, whereas localized illite and some chlorite may have been derived from the Eurasian margin to the north.

8. Petrographic studies of clay clasts indicate all stages of progressive fragmentation to form elongate "shards." The fragmentation and the presence of pseudolamination, crosscutting veinlets, anas- 
tomosing microshears, and shardlike features are attributed to hydrofracturing when overpressured muds rapidly depressurized as extrusion took place.

\section{ACKNOWLEDGMENTS}

Thanks go to the captain, crew, and marine technicians of Leg 160 for outstanding support. Geoff Angel conducted the XRD analysis, whereas Diana Baty assisted with drafting, and Yvonne Cooper helped with photography. Ben Clennell is acknowledged for discussion, SEM studies, and help with XRD analysis on the clay fraction. The manuscript benefited from comments by Angelo Camerlenghi and Michail Ivanov.

\section{REFERENCES}

Akhmanov, G.G., 1996. Lithology of mud breccia clasts from the Mediterrranean Ridge. Mar: Geol., 132:151-164.

Behrmann, J.H., 1991. Conditions for hydrofracture and the fluid permeability of accretionary wedges. Earth Planet. Sci. Lett., 107:550-558.

Berger, W.H., and von Rad, U., 1972. Cretaceous and Cenozoic sediments from the Atlantic Ocean. In Hayes, D.E., Pimm, A.C., et al., Init. Repts. DSDP, 14: Washington (U.S. Govt. Printing Office), 787-954.

Camerlenghi, A., Cita, M.B., Della Vedova, B., Fusi, N., Mirabile, L., and Pellis, G., 1995. Geophysical evidence of mud diapirism on the Mediterranean Ridge accretionary complex. Mar. Geophys. Res., 17:115-141.

Camerlenghi, A., Cita, M.B., Hieke, W., and Ricchiuto, T.S., 1992. Geological evidence for mud diapirism on the Mediterranean Ridge accretionary complex. Earth Planet. Sci. Lett., 109:493-504.

Chamley, H., Dunoyer de Segonzac, G., and Mélières, F., 1978. Clay minerals in Messinian sediments of the Mediterranean area. In Hsü, K.J., Montadert, L., et al., Init. Repts. DSDP, 42 (Pt. 1): Washington (U.S. Govt. Printing Office), 389-395.

Chaumillon, E., and Mascle, J., 1995. Variation laterale des fonts de deformation de la Ride mediterraneenne (Mediterranee orientale). Bull. Soc. Geol. Fr., 166:463-478.

Chaumillon, E., Mascle, J., and Hoffmann, H.J., in press. Deformation of the western Mediterranean Ridge: importance of Messinian evaporitic formations. Tectonophysics.

Cita, M.B., Beghi, C., Camerlenghi, A., Kastens, K. A., McCoy, F., Nosetto, A., Parisi, E., Scolari, F., and Tomadin, L., 1984. Turbidites and megaturbidites from the Herodotus abyssal plain (Eastern Mediterranean) unrelated to seismic events. Mar. Geol., 55:47-62.

Cita, M.B., and Camerlenghi, A., 1990. The Mediterranean Ridge as an accretionary prism in collision context. Mem. Soc. Geol. Ital., 45:463480.

Cita, M.B., Camerlenghi, A., Erba, E., McCoy, F.W., Castradori, D., Cazzani, A., Guasti, G., Giambastiani, M., Lucchi, R., Nolli, V., Pezzi, G., Redaelli, M., Rizzi, E., Torricelli, S., and Violanti, D., 1989. Discovery of mud diapirism in the Mediterranean Ridge: a preliminary report. Boll. Soc. Geol. Ital., 108:537-543.

Cita, M.B., Erba, E., Lucchi, R., Pott, M., van der Meer, R., and Nieto, L., 1996a. Stratigraphy and sedimentation in the Mediterranean Ridge diapiric belt. Mar. Geol., 132:131-150.

Cita, M.B., Ryan, W.B.F., and Paggi, L., 1981. Prometheus mud-breccia: an example of shale diapirism in the Western Mediterranean Ridge. Ann. Geol. Pays Hellen., 30:543-570.

Cita, M.B., Woodside, J.M., Ivanov, M.K., Kidd, R.B., Limonov, A.F., and Scientific Staff of Cruise TTR3 Leg 2, 1995. Fluid venting, mud volcanoes and mud diapirs on the Mediterranean Ridge. Rend. Fis. Acc. Lin. Roma, 5:161-169.

Cita, M.B., Woodside, J.M., Ivanov, M.K., Kidd., R.B., and Limonov, A.F., 1996b. Fluid venting from a mud volcano in the Mediterranean Ridge diapiric belt. Terra Nova, 7:453-458.

Clennell, B., and Maltman, A., 1995. Microstructures in accreted sediments of the Cascadia Margin. In Carson, B., Westbrook, G.K., Musgrave, R.J., and Suess, E. (Eds.), Proc. ODP, Sci. Results, 146 (Pt 1): College Station, TX (Ocean Drilling Program), 201-216.

Dickinson, W.R., and Suczek, C.A., 1979. Plate tectonics and sandstone compositions. AAPG Bull., 63:2164-2182.
Dongarra, G., and Ferla, P., 1982. Le argile di Portella Colla e del Flysch Numidico Auct. (M. Madonie-Sicilia). Aspeti deposizionalii e diagenetici. Rend. Soc. Miner. Petr., 38:1119-1133.

Emeis, K.-C., Robertson, A.H.F., Richter, C., et al., 1996. Proc. ODP, Init. Repts., 160: College Station, TX (Ocean Drilling Program).

Fassoulas, C., Kilias, A., and Mountrakis, D., 1994. Post nappe stacking an extension of high-pressure/low-temperature rocks in the island of Crete, Greece. Tectonics, 13:127-138.

Flandrin, J., 1948. Contribution a l'étude stratigraphique du Nummulitique Algerièn. Boll. Serv. Carte Geol. d'Alger., 19:1-340.

Flecker, R., and Kopf, A., 1996. Data report: clast and grain size analysis of sediment recovered from the Napoli and Milano mud volcanoes, Eastern Mediterranean. In Emeis, K.-C., Robertson, A.H.F., Richter, C., et al., Proc. ODP, Init. Repts., 160: College Station, TX (Ocean Drilling Program), 529-532.

Gieskes, J.M., and Lawrence, J.R., 1981. Alteration of volcanic matter in deep-sea sediments: evidence from the chemical composition of interstitial waters from deep sea drilling cores. Geochim. Cosmochim. Acta, 45:1687-1703.

Guerra, F., Loiacono, F., Puglisi, D., and Moretti, E., 1992. The Numidian nappe in the Maghrebian Chain: state of the art. Boll. Soc. Geol. Ital., 111:217-253.

Hall, R., Audley-Charles, M.G., and Carter, D.J., 1984. The significance of Crete for the evolution of the Eastern Mediterranean. In Dixon, J.E., and Robertson, A.H.F. (Eds.), The Geological Evolution of the Eastern Mediterranean. Geol. Soc. Spec. Publ. London, 17:499-516.

Hower, J., Eslinger, E.V., Hower, M.E., and Perry, E.A., 1976. Mechanism of burial metamorphism of argillaceous sediment. 1. Mineralogical and chemical evidence. Geol. Soc. Am. Bull., 87:725-737.

Hsü, K.J., Montadert, L., et al., 1978. Init. Repts. DSDP, 42 (Pt. 1): Washington (U.S. Govt. Printing Office).

Jennings, S., and Thompson, G.R., 1986. Diagenesis of Plio-Pleistocene sediments of the Colorado River Delta, southern California. J. Sediment. Petrol., 56:89-98.

Kantorowicz, J.D., Bryant, I.D., and Dawans, J.M., 1987. Controls on the geometry and distribution of carbonate cements in Jurassic sandstones: Bridport Sands, southern England and Viking Group, Troll Field, Norway. In Marshall, J.D. (Ed.), Diagenesis of Sedimentary Sequences. Geol. Soc. Spec. Publ. London, 36:103-118.

Kastens, K., 1981. Structural causes and sedimentological effects of the "Coblestone Topography" in the Eastern Mediterranean [Ph.D. dissert.]. Scripps Inst. Oceanography, Univ. of California, San Diego, CA.

Kelts, K., and McKenzie, J.A., 1982. Diagenetic dolomite formation in Quaternary anoxic diatomaceous muds of Deep Sea Drilling Project Leg 64, Gulf of California. In Curray, J.R., Moore, D.G., et al., Init. Repts. DSDP, 64 (Pt. 2): Washington (U.S. Govt. Printing Office), 553-569.

Knipe, R.J., 1986. Microstructural evolution of vein arrays preserved in Deep Sea Drilling Project cores from the Japan Trench, Leg 57. In Moore, J.C. (Ed.), Structural Fabric in Deep Sea Drilling Project Cores from Forearcs. Mem.-Geol. Soc. Am., 166:75-87.

Kopf, A., Sample, J.C., Bauer, P., Behrmann, J.H., and Erlenkeuser, H., 1995. Diagenetic carbonates from Cascadia Margin: textures, chemical compositions, and oxygen and carbon stable isotope signatures. In Carson, B., Westbrook, G.K., Musgrave, R.J., and Suess, E. (Eds.), Proc. ODP, Sci. Results, 146 (Pt 1): College Station, TX (Ocean Drilling Program), 117136.

Land, L.S., and Fisher, R.S., 1987. Wilcox sandstone diagenesis, Texas Gulf Coast: a regional isotopic comparison with the Frio Formation. In Marshall, J.D. (Ed.), Diagenesis of Sedimentary Sequences. Geol. Soc. Spec. Publ. London, 36:219-235.

Le Pichon, X., and Angelier, J., 1979. The Hellenic arc and trench system: a key to the neotectonic evolution of the eastern Mediterranean area. Tectonophysics, 60:1-42.

Limonov, A.F., Ivanov, M.K., and Akhmanov, G.G., 1995. Cobblestone area in the West Mediterranean Ridge: revisited again. Rapp. Comm. Int. Mer Mediterr., 34.

Limonov, A.F., Woodside, J.M., and Ivanov, M.K. (Eds.), 1994. Mud Volcanism in the Mediterranean and Black Seas and Shallow Structure of the Eratosthenes Seamount. Initial Results of the Geological and Geophysical Investigations during the Third "Training-through-Research" Cruise of the R/V Gelendzhik (June-July 1993). UNESCO Rep. Mar. Sci., 64.

Longstaffe, F.J., and Ayalon, A., 1987. Oxygen isotope studies of clastic diagenesis in the Lower Cretaceous Viking Formation, Alberta: implica- 
tions for the role of meteoric water. In Marshall, J.D. (Ed.), Diagenesis of Sedimentary Sequences. Geol. Soc. Spec. Publ. London, 36:277-296.

Martin, B.M., Kastner, M., Henry, P., Le Pichon, X., and Lallement, S., 1996. Chemical and isotopic evidence for sources of fluids in a mud volcano field seaward of the Barbados accretionary wedge. J. Geophys. Res., 101:20325-20345.

Nesteroff, W.D., 1973. Distribution of the fine-grained sediment component in the Mediterranean. In Ryan, W.B.F., and Hsü, K.J., et al., Init. Repts. DSDP, 13 (Pt. 2): Washington U.S. Govt. Printing Office, 666-670.

Premoli-Silva, I., Erba, E., Spezzaferri, S., and Cita, M.B., 1996. Age variation in the source of the diapriric mud breccias along and across the axis of the Mediterranean Ridge Accretionary Complex. Mar. Geol., 132:175-202.

Robertson, A.H.F., 1976. Pelagic chalks and calciturbidites from the lower Tertiary of the Troodos Massif, Cyprus. J. Sediment. Petrol., 46:1000710016.

Robertson, A.H.F., and Ocean Drilling Program Leg 160 Scientific Party, 1996. Mud volcanism on the Mediterranean Ridge: Initial results of Ocean Drilling Program Leg 160. Geology, 24:239-242.

Ryan, W.B.F., and Hsü, K.J., et al., 1973. Hellenic Trench Sites 127 and 128. In Ryan, W.B.F., and Hsü, K.J., et al., Init. Repts. DSDP, 13 (Pt. 2): Washington (U.S. Govt. Printing Office), 243-322.

Ryan, W.B.F., Venkatarathman, K., and Wezel, F.C., 1973. Mineralogical composition of the Nile Cone, Mediterranean Ridge and the Strabo Trench sandstone and clays. In Ryan, W.B.F., and Hsü, K.J., et al., Init. Repts. DSDP, 13 (Pt. 2): Washington (U.S. Govt. Printing Office), 731746.

Schulz, H.M., Emeis, K.C., and Volkmann, N., 1997. Organic carbon provenance and maturity in the mud breccia from the Napoli mud volcano: indicators of origin and burial depth. Earth Planet. Sci. Lett., 144:141151.
Seidel, E., Kreuzer, H., and Harre, W., 1982. A late Oligocene/early Eocene high pressure belt in the external Hellenides. Geol. Jahrb., E23:165-206.

Selley, R.C., 1969. Near-shore marine continental sediments of the Sirte Basin, Lybia. Quart. J. Geol. Soc. London, 124:419-460.

Shinn, E.A., and Robbin, D.M., 1983. Mechanical and chemical compaction in fine-grained shallow-water limestones. J. Sediment. Petrol., 53:595618.

Sibson, R.H., 1981. Controls on low-stress hydro-fracture dilatancy in thrust, wrench and normal fault terrains. Nature, 289:665-667.

Staffini, F., Spezzaferri, S., and Aghib, F., 1993. Mud diapirs of the Mediterranean Ridge: sedimentological and micropalaeontological study of the mud breccia. Riv. Ital. Paleontol. Stratigr., 99:225-254.

Tassé, N., and Hesse, R., 1984. Origin and significance of complex authigenic carbonates in Cretaceous black shales of the western Alps. J. Sediment. Petrol., 54:1012-1027.

Whitney, G., 1990. Role of water in the smectite-to-illite reaction. Clays Clay Miner., 38:343-350.

Yassir, N.A., and Bell, J.S., 1994. Relationships between pore pressures, stresses and present-day geodynamics in the Scotian Shelf, Offshore Eastern Canada. AAPG Bull., 78:1863-1880.

Zemmels, I., and Cook, H.E., 1973. X-ray mineralogy of selected samples from the sea floor of the Northeast Atlantic and Mediterranean Sea. In Ryan, W.B.F., and Hsü, K.J., et al., Init. Repts. DSDP, 13: Washington (U.S.Govt. Printing Office), 605-666.

Date of initial receipt: 15 January 1997

Date of acceptance: 24 June 1997

Ms 160SR-044 


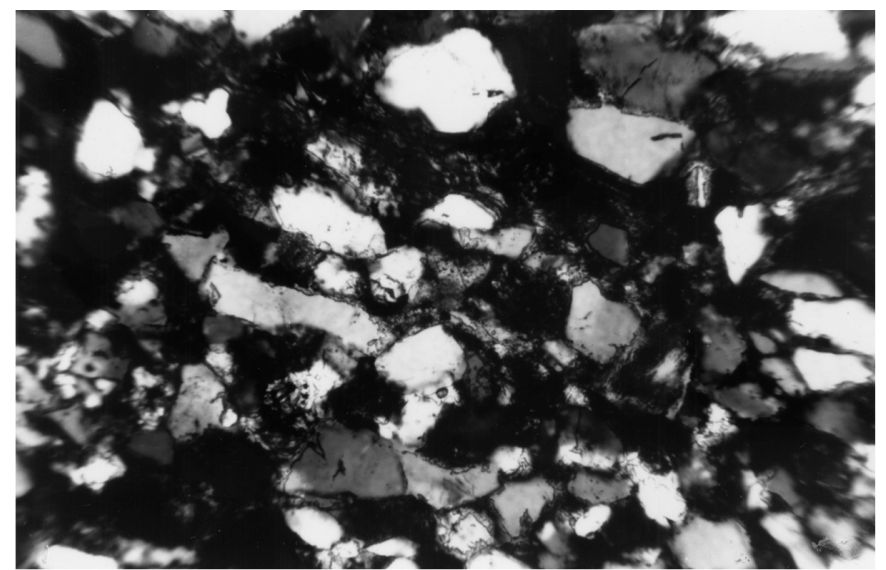

1

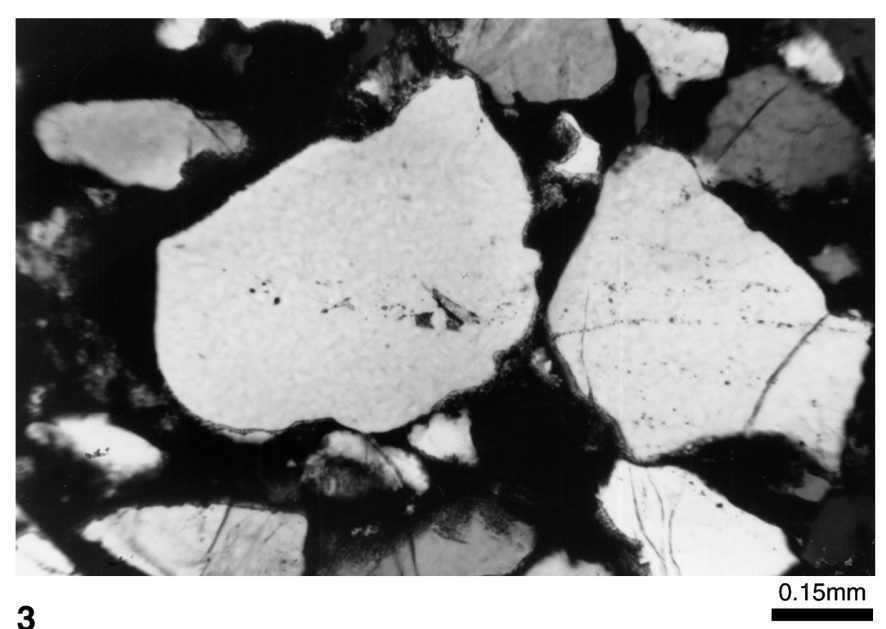

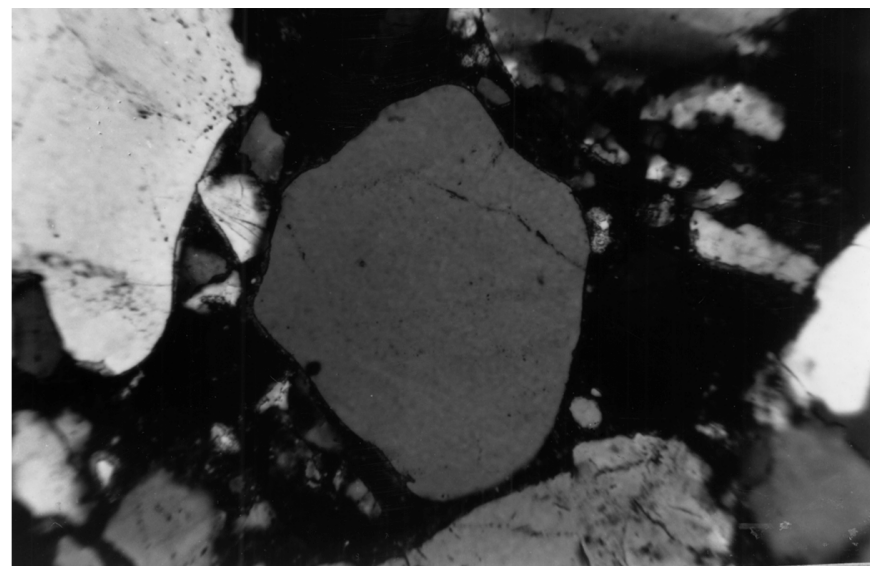

2

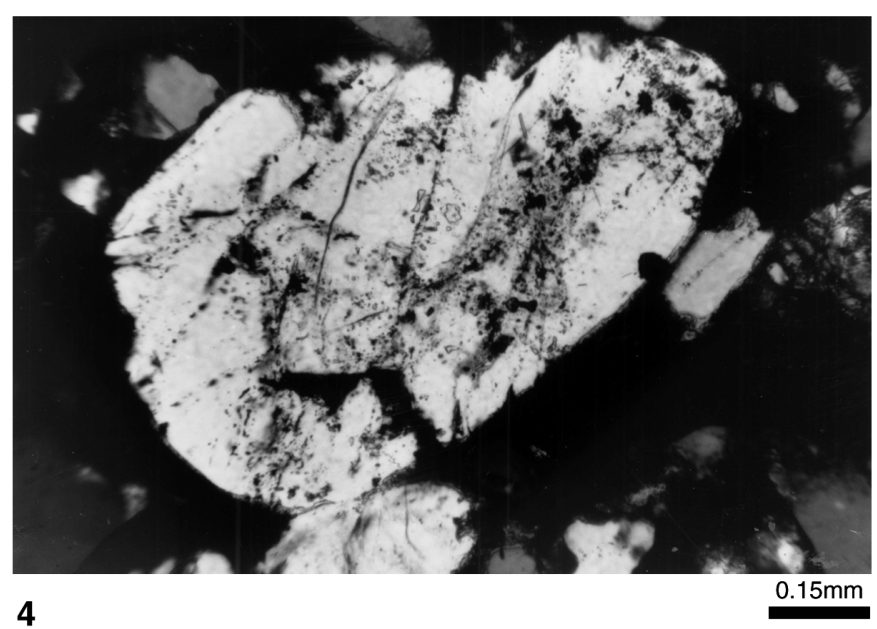

Plate 1. Photomicrographs of clasts from the Milano mud volcano. All viewed under cross-polarized light. 1. Fine quartzose sandstone turbidite showing marked grain alignment (Sample 160-970A-1H-2, 127-130 cm). 2. Medium-grained quartzose sandstone. Note the relatively well-rounded quartz grains, mainly of plutonic or vein origin (Sample 160-970A-1H-2, 127-130 cm). 3. As in figure 2, with relatively mature quartz grains and a subordinate muddy matrix (Sample $160-970 \mathrm{~A}-2,127-130 \mathrm{~cm}$ ). 4. Highly altered feldspar grain in quartz arenite (Sample 160-970A-2, 127-130 cm). 


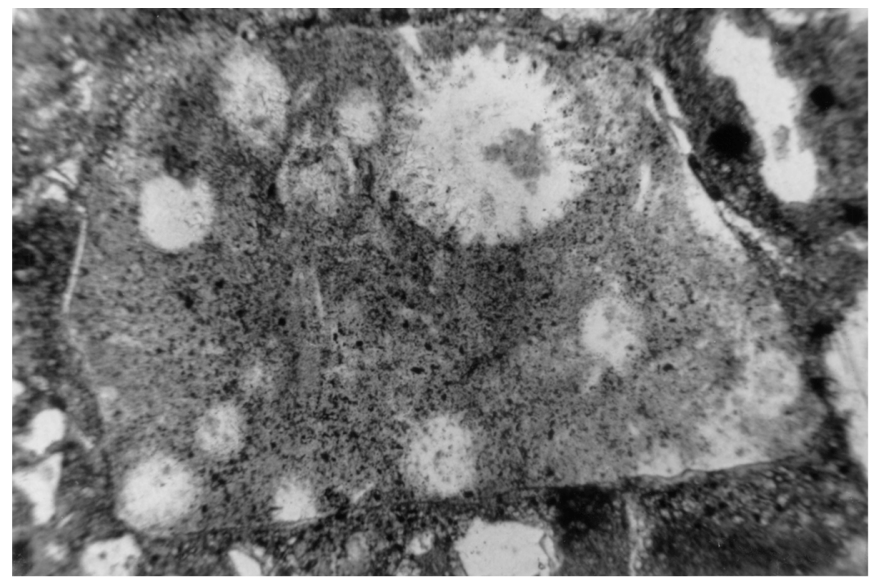

1

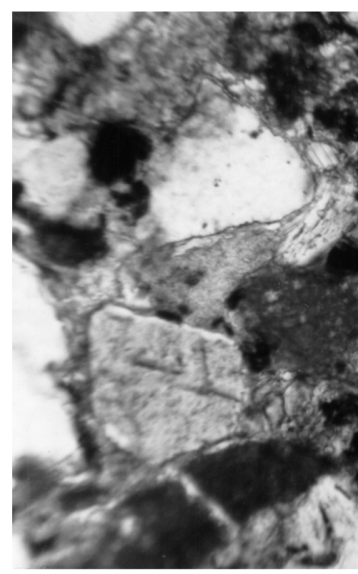

3

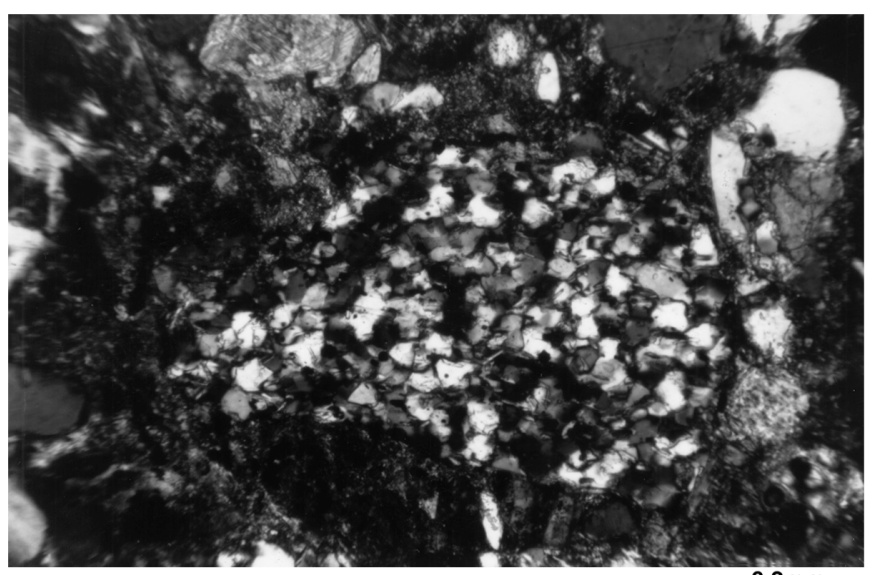

5

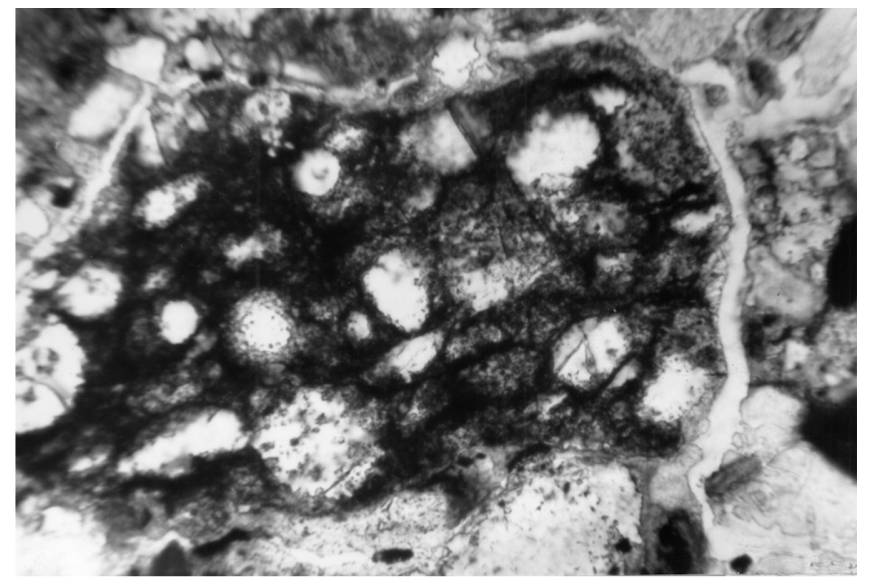

2

$0.25 \mathrm{~mm}$

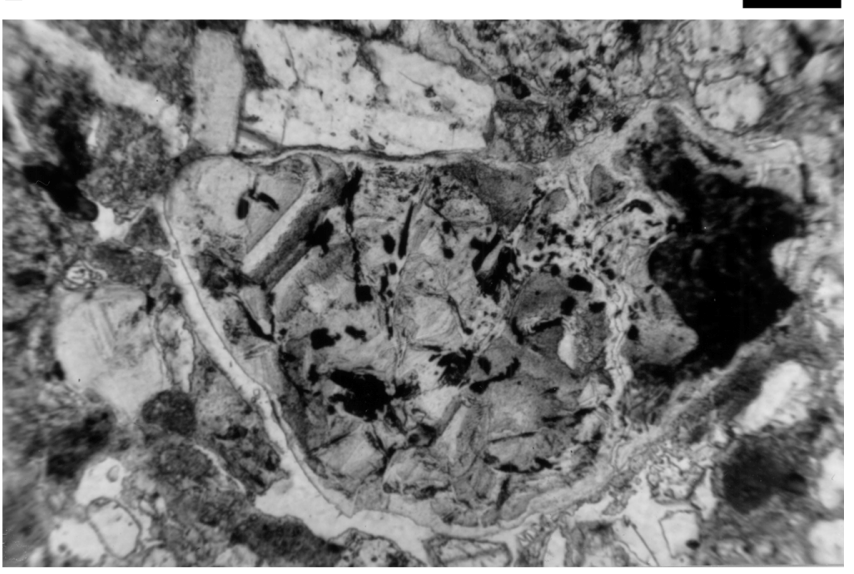

4

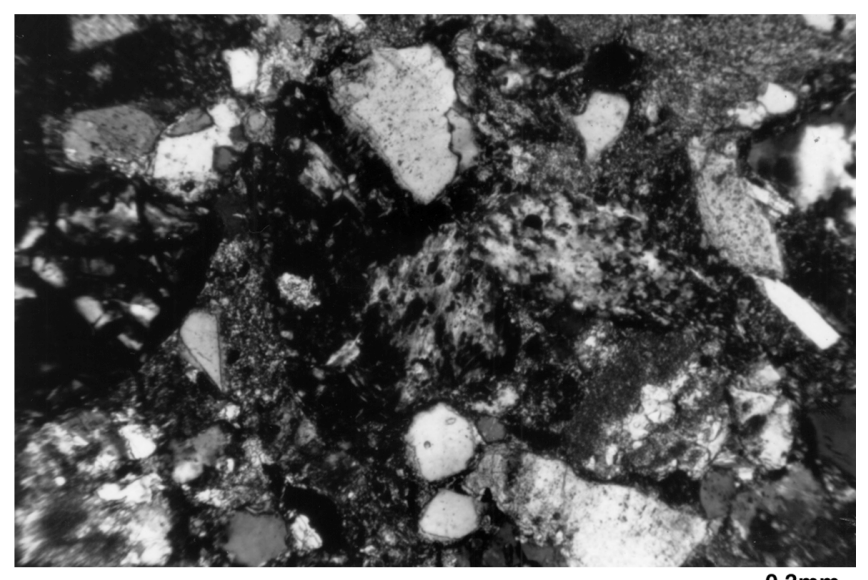

6

$0.3 \mathrm{~mm}$

Plate 2. Photomicrographs of clasts from the Milano (Site 970) and Napoli (Site 971) mud volcanoes. 1. Clast of well-preserved radiolarian chert (plane-polarized light) within lithoclastic sandstone (Sample 160-970D-5H-3, 84-87 cm). 2. Clast of recrystallized radiolarian chert (cross-polarized light) within lithoclastic sandstone (Sample 160-970D-5H-3, 84-87 cm). 3. Clast of extrusive igneous rock with feldspar microphenocryst (plane-polarized light), within lithoclastic sandstone (Sample 160-970D-5H-3, 84-87 cm). 4. Clast of chloritized basic igneous rock (green in plane-polarized light; Sample 160-970D-5H-3, 84-87 cm). 5. Clast of microcrystalline (metamorphic quartz) in lithoclastic sandstone (cross-polarized light; Sample 160-971 A-5X-CC, 29-35 cm). 6. Poorly sorted lithoclastic sandstone with angular grains that include basic extrusive rock (dark), metamorphic quartz (speckled) and quartz (uniformly pale; cross-polarized light; Sample 160-971-5X-CC, 29-35 cm). 

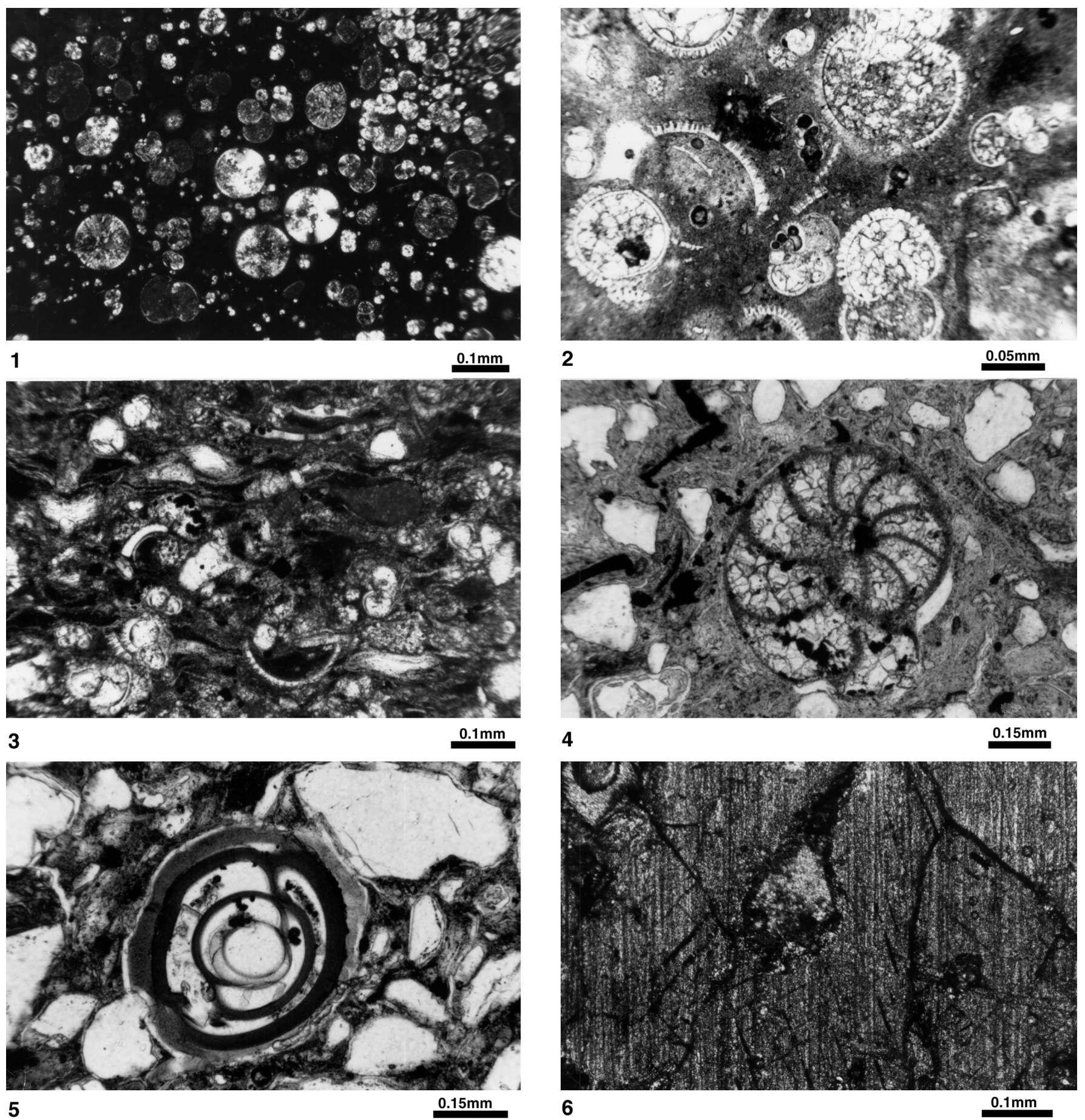

Plate 3. Photomicrographs of clasts from the Milano mud volcano. 1. Pelagic carbonate with planktonic foraminifers scattered through a micritic matrix; tests are empty or filled with micrite or sparry calcite (Sample 160-970C-1H, 26-30 cm). 2. Pelagic carbonate with planktonic foraminifers scattered through a micritic matrix. Note that intact tests are filled with fine sparry calcite (Sample 160-970A-5X-CC, $0-2 \mathrm{~cm}$ ). 3. Calciturbidite with broken and intact foraminifer tests mixed with terrigenous silt and mud (Sample 160-970D-3H-6, 42-49 cm). 4. Mixed carbonate-siliciclastic sediment (turbiditic) with well-preserved benthic foraminifers, with little or no cement fill (Sample 160-970D-3H-6, 42-49 cm). 5. Mixed carbonate-siliciclastic sediment with well-preserved benthic foraminifers, with calcite spar cement (Sample 160-970D-3H-6, 42-49 cm). 6. Detail of crystalline halite clast from the Napoli mud volcano (Sample 160971D-4H-1, 120-22 cm). All photomicrographs were viewed under plane-polarized light, except figure 3, which was under cross-polarized light. 

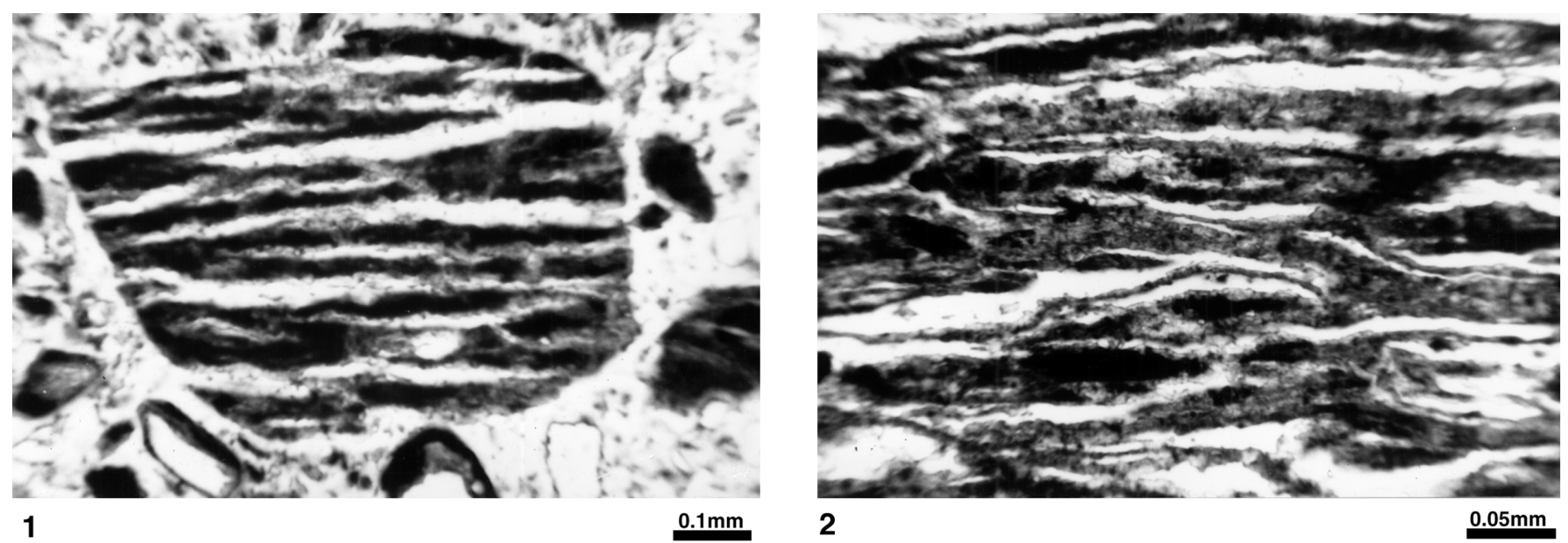

1

$0.1 \mathrm{~mm}$
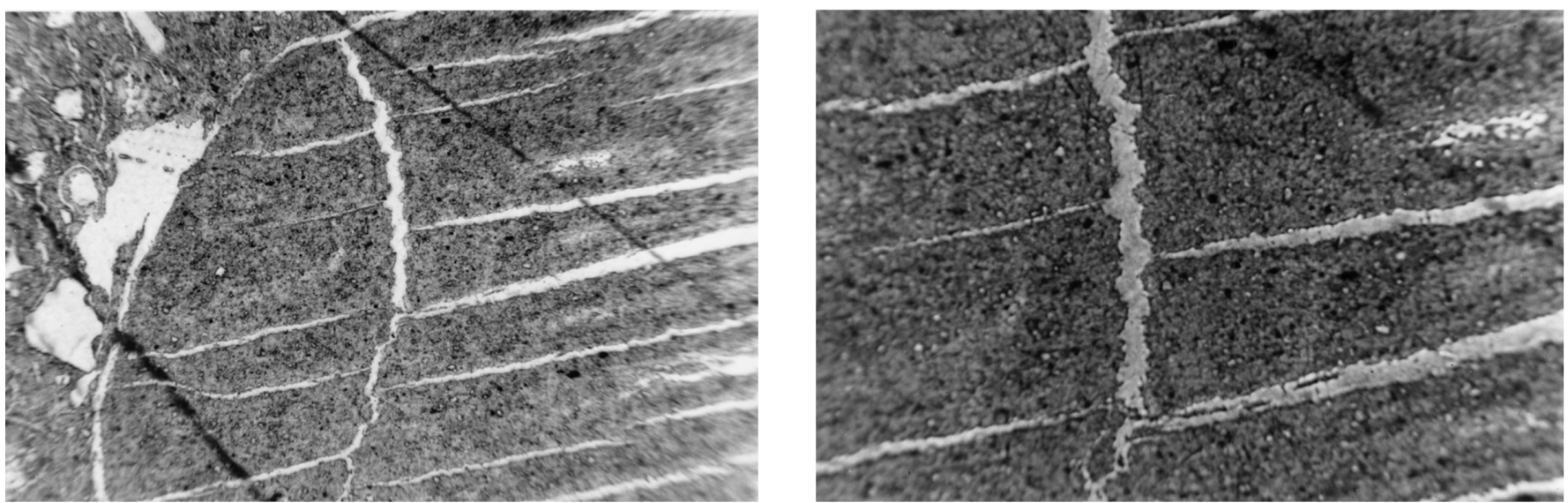

3

$0.5 \mathrm{~cm}$

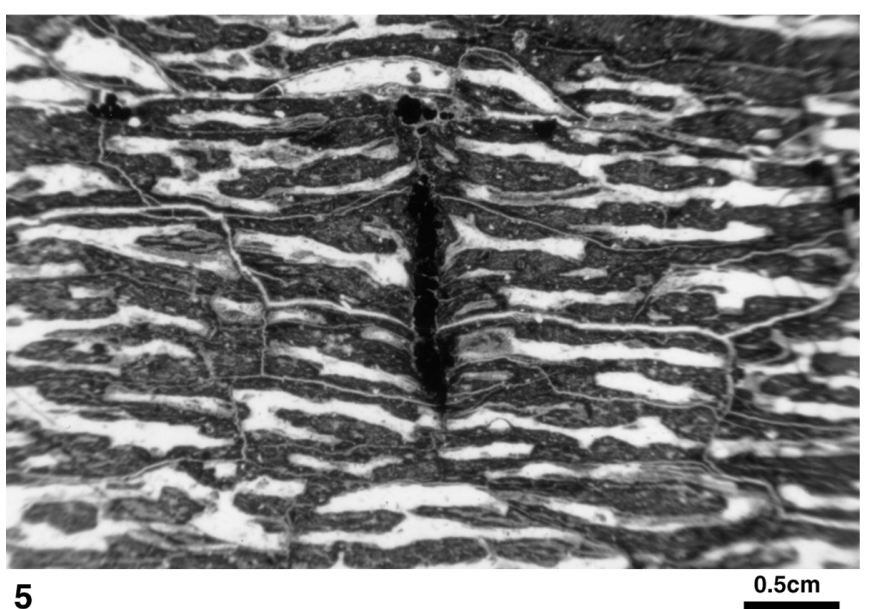

4

$0.2 \mathrm{~mm}$

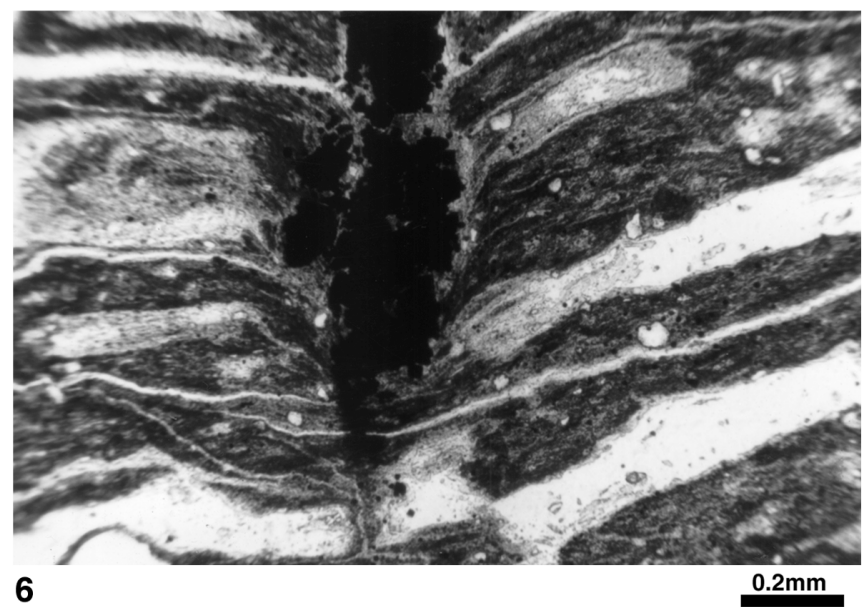

Plate 4. Photomicrographs of mud shards within the Napoli and Milano mud volcanoes. 1. Shardlike mudstone fragment, showing possible evidence of intense shearing. Note that the adjacent matrix is not affected (Sample 160-970B-1H-2, 113-115 cm). 2. Detail of shardlike mudstone fragment, showing possible evidence of intense shearing (Sample 160-970B-1H-2, 113-115 cm). 3. Mudstone clast within debris flows showing crosscutting veins that are interpreted to result from hydrofracturing (Sample 160-970B-1H-2, 113-115 cm). 4. Detail of mudstone clast showing crosscutting veins interpreted as fluid escape conduits (Sample 160-970B-1H-2, 113-115 cm). 5. Diagenetic pyrite (dark), a possible burrow fill, with an irregular pseudolamination deformed against it. The pseudolamination is interpreted to result from shearing and dewatering of overpressured muds within the mud volcano (Sample 160-970D-3H-CC, 17-20 cm). 6. Detail of figure 5. Note the deformation of the pseudolaminae against the pyrite, which indicates deformation while still soft, following formation of the lamina. (All photomicrographs were viewed in plane-polarized light). 

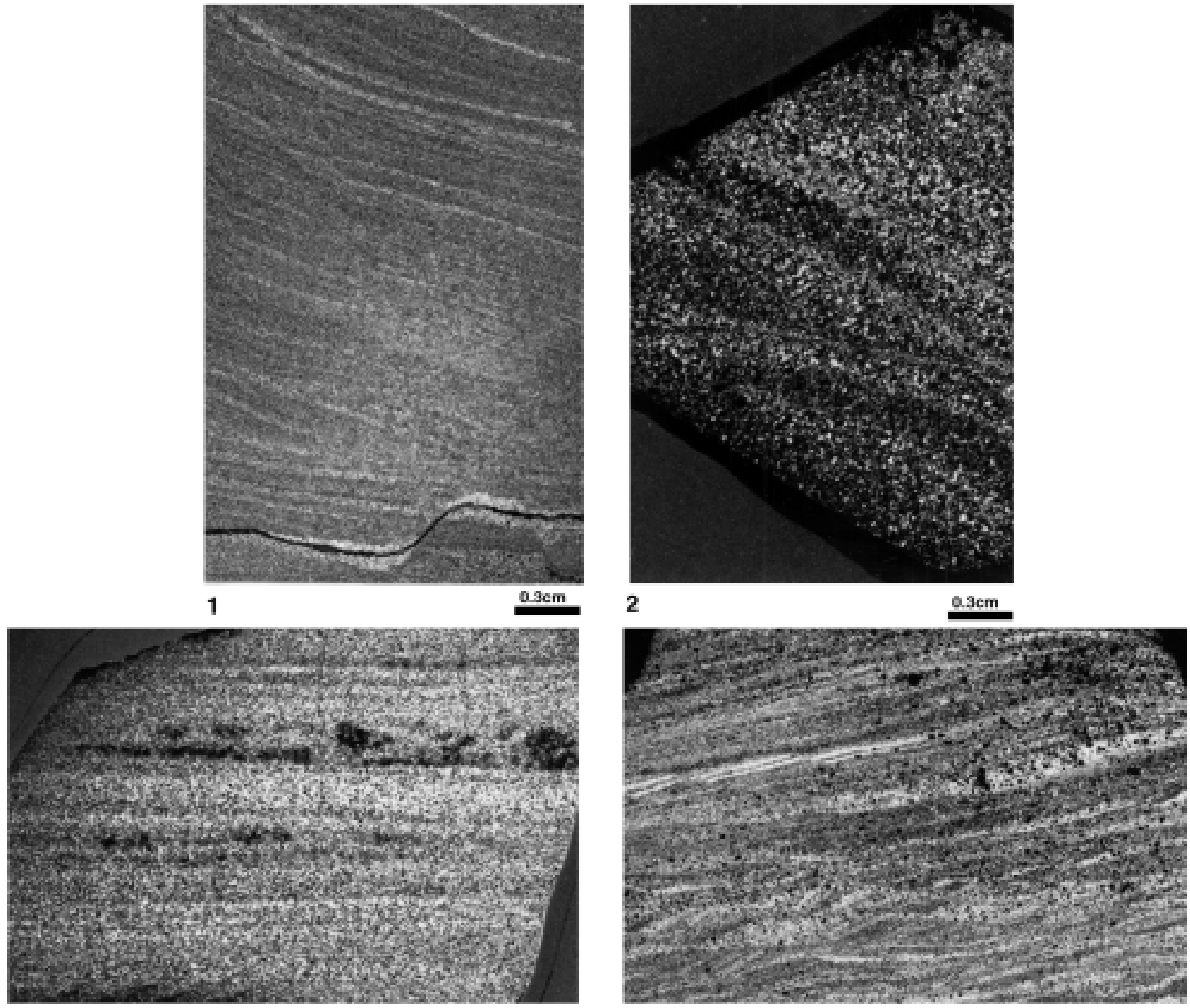

3

$0.3 \mathrm{em}$

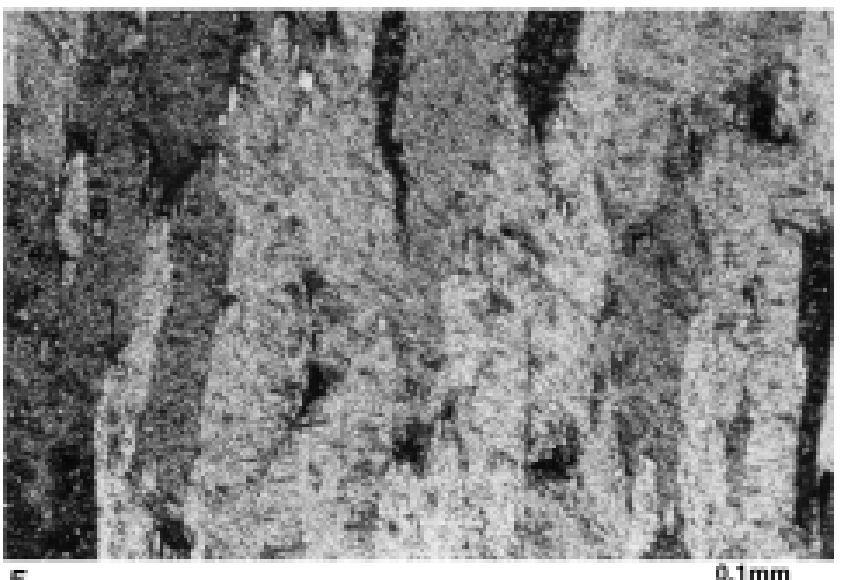

5

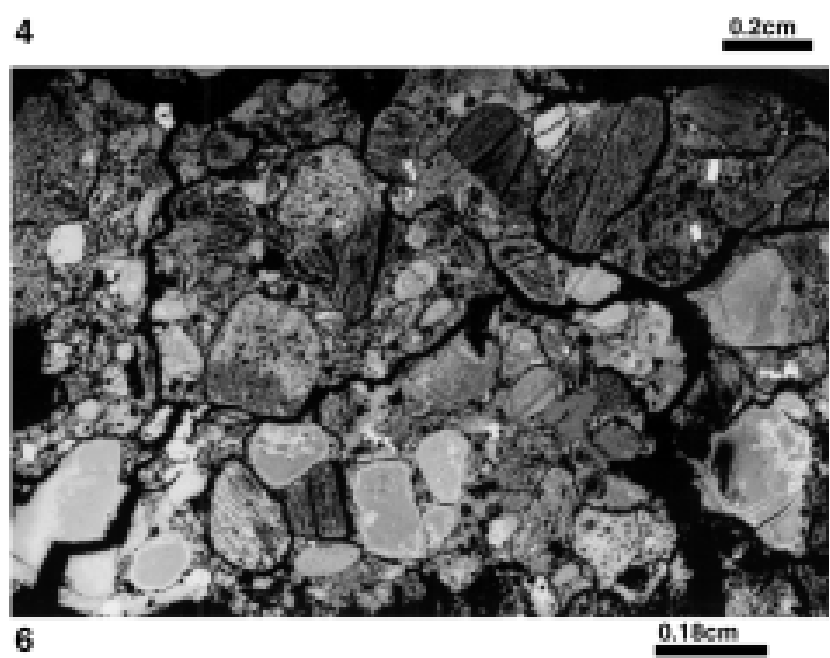

Plate 5. Negative prints of thin sections. 1. Cross lamination in fine sandstone (Sample 160-970C-1H-5, 26-30 cm). 2. Planar lamination with graded partings (Sample 160-970A-1H-5, 42-44 cm). 3. Planar lamination (Sample 160-970A-2H-1, 25-29 cm). 4. Small-scale planar and cross lamination (Sample 160970A-5H-2, 61-64 cm). 5. Massive fibrous calcite, probably from an authigenic vein filling (Sample 160-971A-3H, 110-113 cm). 6. Impregnated sample of lower clastics. Many grains are rounded and show randomly orientated pseudolamination (Sample 160-970A-19X-2, 84-90 cm).

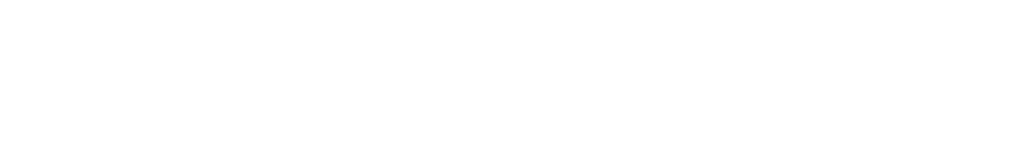

